\title{
The Arabidopsis Downy Mildew Resistance Gene RPP8 Is Induced by Pathogens and Salicylic Acid and Is Regulated by W Box cis Elements
}

\author{
Toni J. Mohr, Nicole D. Mammarella, Troy Hoff, Bonnie J. Woffenden, John G. Jelesko, and \\ John M. McDowell \\ Department of Plant Pathology, Physiology, and Weed Science, Latham Hall (0329), Virginia Tech, Blacksburg, VA, U.S.A. \\ Submitted 21 January 2010. Accepted 21 May 2010.
}

\begin{abstract}
Plants disease resistance $(R)$ genes encode specialized receptors that are quantitative, rate-limiting defense regulators. $R$ genes must be expressed at optimum levels to function properly. If expression is too low, downstream defense responses are not activated efficiently. Conversely, overexpression of $\boldsymbol{R}$ genes can trigger autoactivation of defenses with deleterious consequences for the plant. Little is known about $\boldsymbol{R}$ gene regulation, particularly under defense-inducing conditions. We examined regulation of the Arabidopsis thaliana gene RPP8 (resistance to Hyaloperonospora arabidopsidis, isolate Emco5). RPP8 was induced in response to challenge with $H$. arabidopsidis or application of salicylic acid, as shown with RPP8-Luciferase transgenic plants and quantitative reverse-transcription polymerase chain reaction of endogenous alleles. The $R P P 1$ and $R P P 4$ genes were also induced by $H$. arabidopsidis and salicylic acid, suggesting that some $R P P$ genes are subject to feedback amplification. The RPP8 promoter contains three $W$ box cis elements. Site-directed mutagenesis of all three $W$ boxes greatly diminished RPP8 basal expression, inducibility, and resistance in transgenic plants. Motif searches indicated that the $W$ box is the only known cis element that is statistically overrepresented in Arabidopsis nucleotide-binding leucinerich repeat promoters. These results indicate that WRKY transcription factors can regulate expression of surveillance genes at the top of the defense-signaling cascade.
\end{abstract}

Plants maintain a complex regulatory system for detecting pathogens and activating cellular defense responses. The top of the defense regulatory hierarchy is occupied by two classes of

Current address of T. J. Mohr: Integrative Biology, University of California, Berkeley, CA 94720, U.S.A.

Current address of N. D. Mammarella: Biological and Biomedical Sciences Program, Harvard Medical School, Massachusetts General Hospital, Boston, MA 02114, U.S.A.

Current address of T. Hoff: Edward Via Virginia College of Osteopathic Medicine, Blacksburg, VA 24060, U.S.A.

Current address of B. J. Woffenden: Edgewood Chemical Biological Center, U.S. Army Research, Development and Engineering Command, Aberdeen Proving Ground, MD 21010-5424, U.S.A.

Corresponding author: John M. McDowell; Telephone: +1.540.231.2388; E-mail: johnmcd@vt.edu

* The $e$-Xtra logo stands for "electronic extra" and indicates that nine supplementary tables are published online. receptors (Chisholm et al. 2006; Jones and Dangl 2006). First, pattern recognition receptors (PRR) can recognize pathogenassociated molecular patterns (PAMPS) to activate PAMP-triggered immunity (PTI). Second, plant resistance (R) proteins can detect specific pathogen avirulence (Avr) or effector proteins that are secreted by pathogens to subvert plant regulatory pathways. This effector-triggered immunity (ETI) can be initiated through direct contact between the $\mathrm{R}$ protein and the cognate effector or through perceived alteration of the effector's virulence target (Dangl and McDowell 2006). The majority of $R$ genes encode proteins containing a nucleotide-binding site and leucine rich repeats (NB-LRR proteins) (Collier and Moffett 2009; Takken and Tameling 2009). Some $R$ genes encode proteins with a presumptive coiled-coil domain at the $\mathrm{N}$ terminus (CC-NB-LRR), while others encode proteins with an $\mathrm{N}$-terminal domain resembling the cytoplasmic signaling module of metazoan toll-like and interleukin 1 receptors that mediate innate immunity (TIR-NB-LRR).

A complex signaling network supports the recognition function of $\mathrm{R}$ proteins. $\mathrm{R}$ protein-dependent pathogen recognition is typically followed by accumulation of reactive oxygen intermediates (ROI), nitric oxide (NO), and the phenolic compound salicylic acid (SA) (McDowell and Dangl 2000). The exact roles of these small molecules in defense signaling remain to be clarified but several studies suggest that they interact with each other in a signal amplification loop (Delledonne et al. 1998, 2001; Durner et al. 1998; Shirasu et al. 1997). Additional components of the defense network have been revealed by genetic approaches. These include the SA biosynthetic enzyme ICS1 (Wildermuth et al. 2001) and putative lipases encoded by the EDS1, PAD4, and SAG101 genes (Falk et al. 1999; Feys et al. 2005; Jirage et al. 1999; Wiermer et al. 2005). PAD4, EDS1, and SAG101 interact physically and operate in the same signaling pathway, upstream of SA accumulation (Feys et al. 2001, 2005; Wiermer et al. 2005). EDS1 and PAD4 are induced during defense activation, possibly through feedback loops that involve SA (Feys and Parker 2000; Wiermer et al. 2005).

Microarray studies indicate that the plant transcriptome undergoes extensive reprogramming during defense activation (Katagiri 2004). Several classes of transcription factors have been associated with defense-associated gene regulation (Chen et al. 2002; Gutterson and Reuber 2004; Singh et al. 2002). One of the most extensively studied defense transcription regulator is NPR1, an ankrin-repeat containing, redox-regulated protein that acts downstream of SA and jasmonic acid accumulation. Several lines of evidence suggest that NPR1 defines a point of convergence (node) for multiple signaling pathways in the defense network (Dong 2004; Katagiri 2004). 
The WRKY superfamily of transcription factors also plays a central role in defense regulation (Eulgem and Somssich 2007; Pandey and Somssich 2009). WRKY proteins are defined by a 60-amino-acid DNA-binding module containing a putative zinc finger and the amino acid sequence WRKYGQK. The cognate cis element for WRKY proteins ('W box') contains the consensus (T)TGAC(C/T) (Eulgem et al. 2000). W boxes are often statistically overrepresented in promoters of defenseassociated genes (Chen et al. 2002; Eulgem et al. 2004; Maleck et al. 2000; Navarro et al. 2004; Zipfel et al. 2004), and mutational analyses of $\mathrm{W}$ boxes in several genes have clearly demonstrated their relevance to immune regulation (Eulgem et al. 1999; Lebel et al. 1998; Turck et al. 2004; Yu et al. 2001). W boxes sometimes occur as clusters and can act synergistically (Eulgem et al. 1999). Individual WRKY proteins can act as positive or negative regulators and, collectively, regulate multiple levels within the defense signaling hierarchy (Du and Chen 2000; Eulgem et al. 1999; Journot-Catalino et al. 2006; Kim et al. 2008; Knoth et al. 2007; Laloi et al. 2004; Lebel et al. 1998; Turck et al. 2004; Wang et al. 2006; Yu et al. 2001). Intriguingly, the NB-LRR protein Mla10 from barley enters the nucleus and interacts with WRKY proteins that function as negative regulators of PTI, demonstrating a direct link between pathogen perception and transcriptional regulation of immune responses (Shen et al. 2007).

Although the mechanisms of $\mathrm{R}$ protein functionality have been intensively studied, very little is known about the mechanisms that regulate $R$-gene expression. Several studies have demonstrated that $R$ genes from diverse species are transcriptionally upregulated in response to pathogens and other environmental stimuli (Cao et al. 2007; Chandra-Shekara et al. 2004; Eulgem et al. 2007; Gu et al. 2005; Halterman et al. 2003; Kramer et al. 2009; Levy et al. 2004; Navarro et al. 2004; Romer et al. 2007; Shirano et al. 2002; Wang et al. 2001; Xiao et al. 2003; Yoshimura et al. 1998; Zipfel et al. 2004). In contrast, transcript levels of other $R$ genes do not change during pathogen attack, indicating that $R$ genes may vary in their pathogen responsiveness (Ayliffe et al. 1999; Boyes et al. 1998; Collins et al. 1999; Huang et al. 2005; Mes et al. 2000; Tan et al. 2007). Many $R$ genes exhibit incomplete dominance; heterozygous plants with only one functional allele ( $R r$ genotype) mount a delayed resistance response compared with $R R$ homozygotes, resulting in a longer window of opportunity for pathogen reproduction (Holt et al. 2005; McDowell et al. 1998; Reignault et al. 1996; van der Biezen et al. 2002). This dosedependency is consistent with molecular studies demonstrating that resistance can be significantly compromised if $\mathrm{R}$ protein abundance falls below a critical threshold (Bieri et al. 2004; Holt et al. 2005). Accordingly, recent studies have established correlations between transcript abundance and effectiveness of resistance conferred by transgenic $R B$ in potato (Bradeen et al. 2009; Kramer et al. 2009) and Xa3 in rice (Cao et al. 2007). However, $R$-gene overexpression can be harmful: transgenic studies have demonstrated that $R$-gene overexpression can cause growth retardation, spontaneous cell death, and constitutive defense activation (Bendahmane et al. 2002; Shirano et al. 2002; Stokes et al. 2002; Tao et al. 2000). In sum, it is clear that proper control of $R$-gene expression is an important aspect of defense network functionality. However, information on cis elements, trans factors, and regulatory pathways governing $R$-gene transcription is only beginning to emerge (discussed below).

The objectives of this study were to characterize the expression of several Arabidopsis thaliana RPP genes (for resistance to the oomycete Hyaloperonospora arabidopsidis), identify candidate $c$ is regulatory elements, and obtain a global view of the extent to which NB-LRR genes are pathogen responsive. Most of the experiments in this study focused on the RPPS gene from the Landsberg erecta ecotype (RPP8-Ler), its paralog $R P H 8 A$, and the RPP8 allele from the Columbia (Col) ecotype (RPP8-Col). RPP8-Ler and RPH8A comprise a two-gene cluster in Ler (McDowell et al. 1998) (Fig 1A). In contrast, the $R P P 8$ locus in Columbia contains a single gene with a chimeric structure, indicating that it arose by recombination between ancestral copies of RPP8-Ler and RPH8A (McDowell et al. 1998). RPP8-Ler encodes a CC-NB-LRR protein that specifies resistance to the Emco5 and Emwal isolates of $H$. arabidopsidis. The functions of RPP8-Col and RPH8A are currently unknown. RPH8A and RPP8-Col are both transcribed and encode full-length proteins with $>90 \%$ identity to RPP8-Ler (McDowell et al. 1998). RPP8-Col (At5g43470) is not represented on the Ath1 Affymetrix microarray; therefore, no information about its expression is available from datasets generated using this chip.

Two additional alleles of $R P P 8$, called $H R T$ and $R C Y 1$, provide resistance to Turnip crinkle virus in the Dijon 17 ecotype and Cucumber mosaic virus in the C24 ecotype, respectively (Cooley et al. 2000; Takahashi et al. 2002). Both of these alleles are composed of a single gene with a chimeric structure similar to RPP8-Col. It was recently reported that $H R T$ is induced by application of exongenous SA or glycerol, or by mutations that impair biosynthesis of oleic acid (ChandraShekara et al. 2004, 2007). HRT is not induced during infection by Turnip crinkle virus.

Here, we report that RPP8-Ler, RPH8A, and RPP8-Col are induced by $H$. arabidopsidis and by exogenous SA. We also determined that the TIR-NB-LRR genes RPPl (Botella et al. 1997) and RPP4 (van der Biezen et al. 2002) are induced by $H$. arabidopsidis. We identified three $\mathrm{W}$ boxes in the RPP promoter and used site-directed mutagenesis to demonstrate that one or more of these elements is necessary for RPPS expression and function. The $\mathrm{W}$ box is the only known cis element that is statistically overrepresented within Arabidopsis

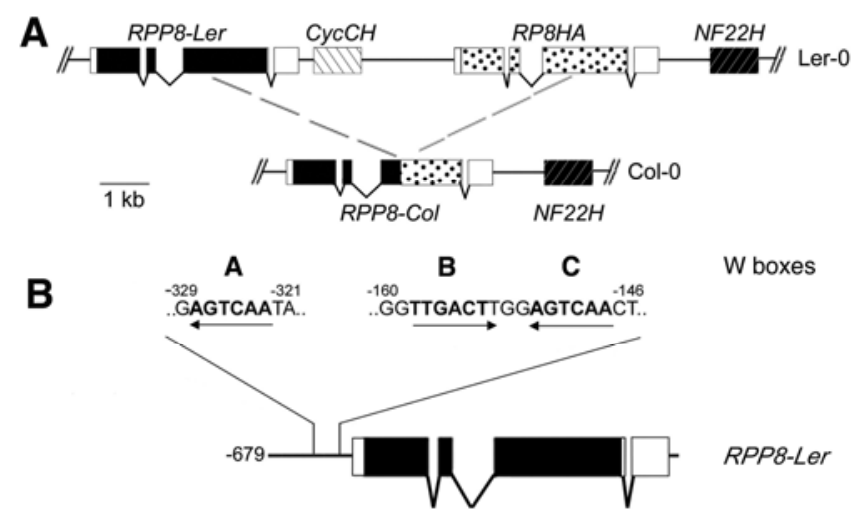

C

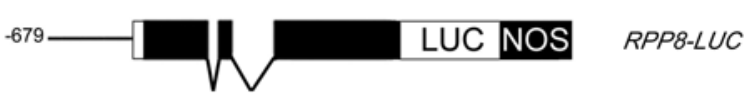

Fig. 1. Structure of RPP8-Ler, RPP8-Col, and the RPPS-LUC reporter gene. A, The RPP8 locus in the Landsberg erecta (Ler-0) and Columbia (Col-0) ecotypes of Arabidopsis thaliana. Symbols: 5' and $3^{\prime}$ untranslated regions are shown as open boxes, protein-coding regions are shown as filled boxes, introns are depicted by diagonal lines, and dashed lines indicate the region deleted in the Col-0 locus, relative to Ler-0. $\mathrm{CycCH}$ and $N F 22 H$ designate adjacent genes (McDowell et al. 1998). B, Structure of the wild-type RPP8-Ler transgene used in this study. The expanded section depicts the relative orientation and location, upstream of the translation start site, of three $\mathrm{W}$ boxes in the RPP8 promoter, named $\mathrm{W}^{\mathrm{RPP} 8} \mathrm{~A}$, $\mathrm{W}^{\mathrm{RPP} 8} \mathrm{~B}$, and $\mathrm{W}^{\mathrm{RPP} 8} \mathrm{C}$, denoted by $\mathrm{A}, \mathrm{B}$, and $\mathrm{C}$ in this figure. $\mathrm{C}$, Structure of the $R P P 8-L U C$ construct. The firefly luciferase gene $(L U C)$ is translationally fused to the exact $3^{\prime}$ end of the RPP8-Ler coding region and is followed by the nopaline synthase $(N O S)$ transcription terminator. 
NB-LRR promoters. These observations potentially broaden the role of WRKY proteins as defense regulators, and suggest a mechanism by which $R$ genes are upregulated to boost defense response efficiency. Our global analyses of Arabidopsis NB-LRR expression, using publicly available microarray data, revealed a high degree of variability in the responses of $R$ genes to pathogens and pathogen-related stimuli.

\section{RESULTS}

\section{$R P P 8, R P P 1$, and $R P P 4$ are induced}

in response to $H$. arabidopsidis and exogenous SA.

To visualize spatial and temporal expression of RPP8, we created transgenic Col-0 plants containing a translational fusion of the full-length $R P P 8$-Ler gene to the firefly Luciferase reporter gene (RPP8-LUC) (Fig. 1C). The RPP8-LUC fusion includes the entire $R P P 8-L e r$ protein-coding region, translationally fused to $L U C$ and the nopaline synthase (NOS) transcription terminator. This fusion was driven by the native $R P P 8$ Ler promoter, consisting of 679 bp upstream of the start codon. This promoter was previously shown by transgenic complementation to be sufficient for a fully functional gene (McDowell et al. 1998). An analogous RPH8A-LUC fusion was constructed in parallel, consisting of $1.8 \mathrm{~kb}$ of $5^{\prime}$ flanking sequence followed by the entire RPH8A coding region, fused to $L U C$ and NOS. Each construct was transformed into Col-0 by floral dipping, and T3 homozygous populations were isolated from three independent lines of Col::RPPB-LUC and three lines of Col::RPH8A-LUC.

We began our analyses of Col::RPP8-LUC and Col::RPH8A$L U C$ lines by monitoring untreated plants for 29 days following germination, to determine basal expression levels under optimal growth conditions. T3 plants were sprayed with $1 \mathrm{mM}$ luciferin in $0.01 \%$ Triton-X100, and luciferase activity was assayed by a photomultiplier connected to a CCD camera system. Luciferase activity was quantified by measuring the incident photons from an area that encompassed the entire rosette of an individual plant over a 20-mi time course. Untransformed plants were assayed in parallel to estimate background 'heat' photons (typically 100 to 200 photons per $20 \mathrm{~min}$ ). All six lines showed very low levels of luciferase activity over this time course. Luciferase activity was slightly higher in Col:: RPP8-LUC lines compared with Col::RPH8A-LUC lines (Fig. $2 \mathrm{C}$ and $\mathrm{D})$.
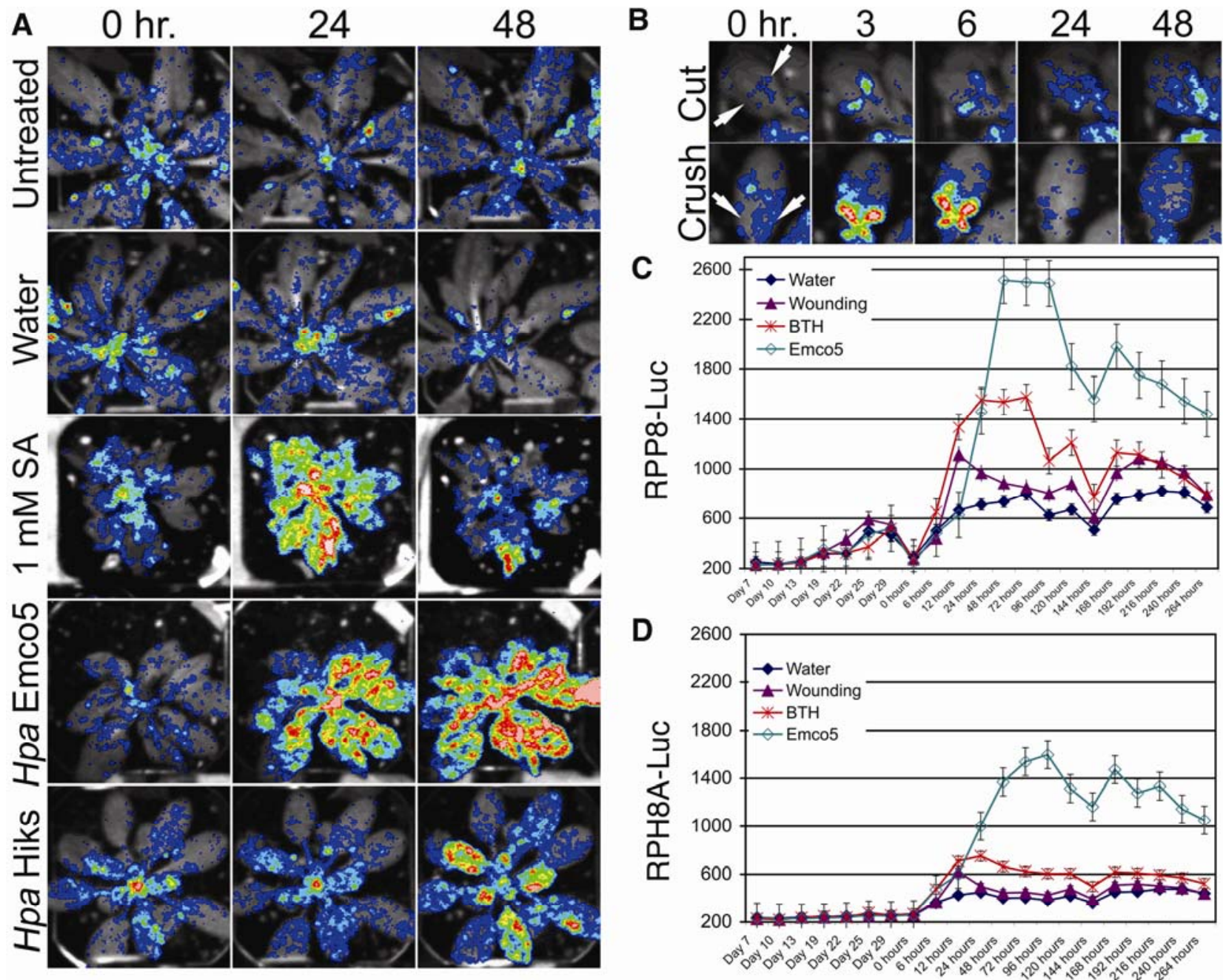

Fig. 2. Induction of the RPP8-LUC transgene in response to Hyaloperonospora arabidopsidis, exogenous salicylic acid (SA), or wounding. A, Light emission from Col::RPP8-LUC transgenic plants at 0,24 , and $48 \mathrm{~h}$ after application of $1 \mathrm{mM}$ salicylic acid, or inoculation with H. arabidopsidis isolates Emco5 or Hiks1. Water-treated and untreated control plants are shown. B, Wound responses of representative leaves from Col::RPP8-LUC plants, which were subjected to single cuts with scissors or crushing with forceps on each side of the midvein. White arrows depict wound sites. C, Time course of luciferase activity in $\mathrm{T} 3$ progeny from a single $R P P 8-L U C$ transgenic line. The $\mathrm{X}$-axis depicts the number of apparent photons emitted from individual plants over a 20-min time course. Bars depict the mean and standard deviation from five individual plants. D, Time course of luciferase activity from a single RPH8A-LUC line. All images and graphs are representative of experiments performed on two to three transgenic lines, each with at least two replicates. Similar results were observed in each experiment. 
Experimental treatments were applied on day 30. Inoculation with Emco5 provoked an increase in luciferase activity within $6 \mathrm{~h}$. Emco5-induced luciferase activity reached a maximum between 48 and $72 \mathrm{~h}$ after infection and then gradually declined (Figs. 2A and $\mathrm{C}$ ). Three independently transformed RPP8-LUC lines exhibited similar qualitative expression changes, with quantitative variation ranging from two- to sevenfold induction relative to water-treated controls. RPP8-LUC did not provide resistance to $H$. arabidopsidis Emco5 in Col seedlings, presumably due to interference of RPP8 activity caused by the additional LUC protein sequence (data not shown). However, adult Col plants express a developmentally regulated resistance against Emco5, which is conditioned by the RPP31 locus on chromosome 5 (McDowell et al. 2005). Thus, the expression changes shown in Figure 2 occurred in the context of an RPP31-dependent resistance response.

Benzothiadiazole $(\mathrm{BTH})$ treatment provoked a weaker and more transient response, compared with Emco5, in RPP8-LUC (Fig. 2C). Independent treatments with $1 \mathrm{mM}$ SA provoked a similar upregulation but the kinetics were somewhat accelerated compared with Emco5-induced responses (Fig. 2A). Wounding with scissors or forceps provoked faster but weaker and more transient upregulation of RPP8-LUC expression levels (Fig. 2B and C).

Three independent lines of RPH8A-LUC displayed consistent upregulation after Emco5 challenge. However, the responses were generally slower and weaker (approximately twofold lower) than those observed in Col::RPPS-LUC lines (Fig. 2D). $R P H 8 A-L U C$ lines displayed very weak luciferase activity and inconsistent responsiveness to BTH treatment and wounding.

Additional experiments were conducted on one representative RPP8-LUC line. The induction of RPP8-LUC during $R P P 31$-dependent resistance indicated that $R P P 8$ induction is not specifically dependent on $R P P 8$ function, and might be a consequence of general defense activation. To test this further, we examined RPP8-LUC activity in plants inoculated with $H$. arabidopsidis Hiks1, which is recognized by the RPP7 gene in $\mathrm{Col}$ (McDowell et al. 2000). We observed significant induction of RPP8-LUC during in response to the Hiks1 (Fig. 2A). This result further verifies that $R P P 8-L U C$ upregulation is not specifically dependent on $R P P 8$ functionality, and can be activated by multiple $H$. arabidopsidis isolates.

The SA responsiveness of $R P P B-L U C$ indicated that $R P P 8$ might be regulated by additional signals that are induced downstream of pathogen recognition. To explore this further, we tested whether RPPS-LUC was induced by application of $50 \mathrm{mM}$ methyl jasmonate, $20 \mathrm{mM} 2,4 \mathrm{D}, 1 \%$ hydrogen peroxide, or $150 \mathrm{mM}$ of the ROI generator rose bengal. RPP $8-L U C$ activity was not altered by any of these treatments (data not shown).

To confirm that RPP8-LUC is an accurate reporter, we assayed RPP8-Ler mRNA with real-time polymerase chain reaction (PCR). Design of a gene-specific assay was complicated by the high degree of identity between RPP8-Ler, RPH8A, and paralogous relatives. We designed a Taqman probe and primers against a region of the RPP8-Ler $3^{\prime}$ untranslated region (UTR). This region is divergent in all $R P P 8$ paralogs and alleles except for $R P H 8 A$, which is identical to RPP8-Ler in the $3^{\prime}$ UTR. We used these primers for two sets of experiments. First, we assayed mRNA from the Landsberg erecta ecotype, which contains the endogenous, functional allele of RPP8. These experiments indicated that the endogenous RPP8-Ler transcript increased in response to treatment with Emco5 by approximately twofold between 24 and $48 \mathrm{~h}$ after inoculation (Fig. 3A). However, we could not make specific conclusions about RPP8-Ler transcript abundance, because this assay detects mRNA from RPP8-Ler and RPH8A. Accordingly, we performed a second set of assays on transcripts from an RPP8Ler transgene (genomic clone without LUC) (Fig. 1B), in the Col background. Control experiments with nontransgenic Col confirmed that the PCR primers and Taqman probe do not detect the endogenous RPP8-Col allele or paralogous genes (data not shown). Thus, the Taqman assays on Col::RPP8-Ler transgenic lines specifically report RPP8-Ler mRNA abundance. We observed that RPP8-Ler transcript increases in response to SA and Emco5 in five independent Col::RPP8-Ler lines (Fig. 3B and data not shown). The magnitude of induction varied between lines but, in most cases, was in the range of two- to sevenfold. Transgenic RPPS-Ler transcripts were most abundant $24 \mathrm{~h}$ after inoculation, and diminished again at $48 \mathrm{~h}$. We also assayed mRNA from the endogenous $R P P 8-C o l$
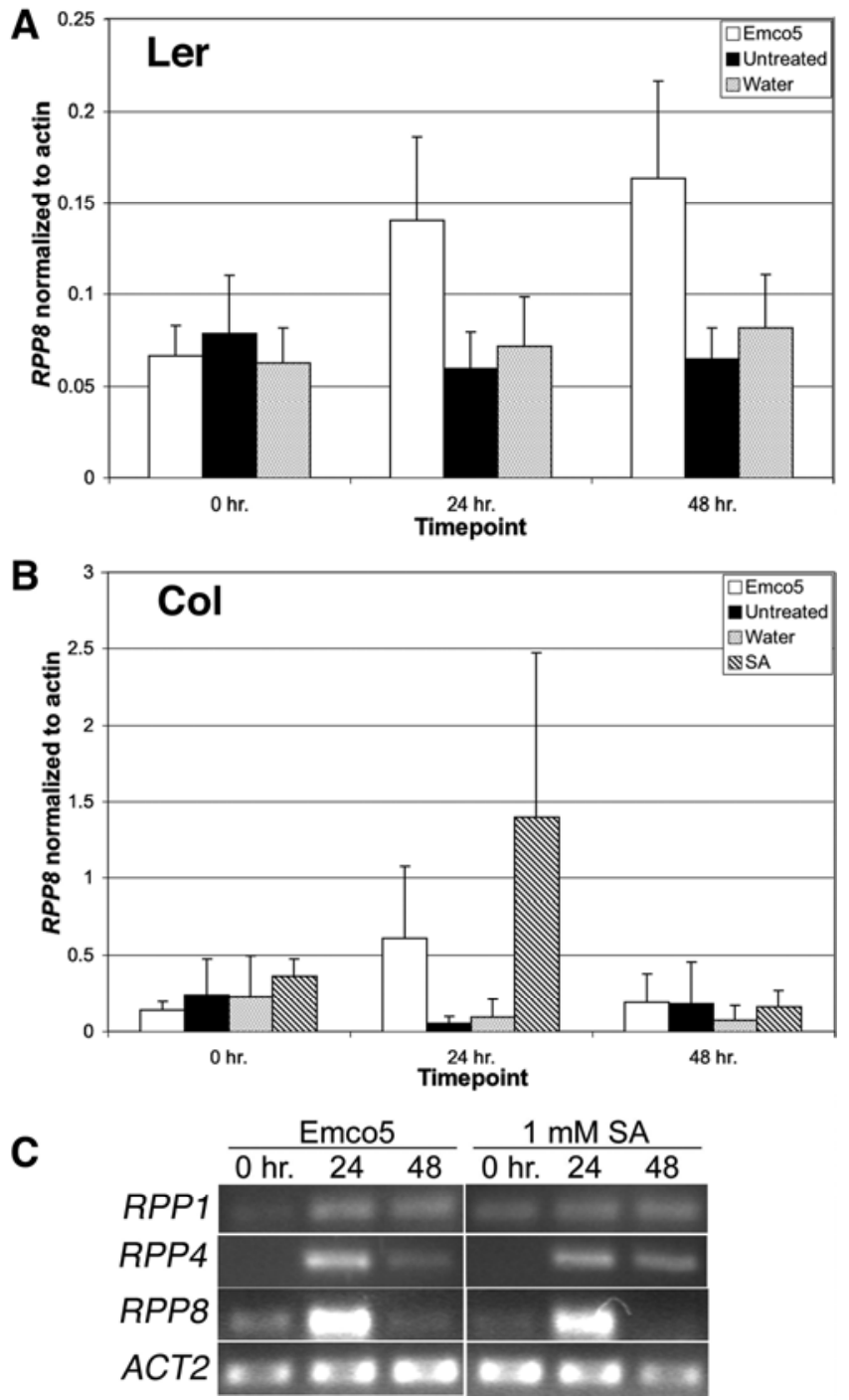

Fig. 3. Abundance of mRNA from RPP8-Ler and RPP8-Col, in response to Hyaloperonospora arabidopsidis and salicylic acid (SA). A, Taqman assays of $R P P 8$ transcript in the Landsberg erecta ecotype. This assay amplifies transcripts of RPP8-Ler and the highly homologous gene RP8HA; thus, the graph represents expression of both genes. ACT2 transcript was used for normalization. Bars depict mean and standard deviation from three independent biological replicates, each with two technical replicates from independent cDNA preparations. B, Taqman assays of transcript from an RPP8-Ler transgene in the Columbia ecotype. This assay is specific for RPP8-Ler expression. Bars depict the mean and standard deviation from assays of three independently transformed transgenic lines. $\mathbf{C}$, Semiquantitative polymerase chain reaction of endogenous alleles of $R P P 8, R P P 4$, and $R P P 1$ in the Columbia background. This experiment was repeated three times, with similar results. 
allele (At5g43470). The RPP8-Col allele has a promoter very similar to that of RPP8-Ler and, therefore, would be expected to undergo similar upregulation in response to pathogens and SA. This was confirmed by semiquantitative reverse-transcription (RT)-PCR in an Emco5-resistant background (Col with an RPP8-Ler transgene) (Fig. 3C). These results demonstrate that multiple alleles of $R P P 8$ are responsive to avirulent pathogens and to exongenous SA. Moreover, RPP8-Col is induced by Emco5 in a susceptible background (Col with a silenced version of RPP8-Ler) (Fig. 4C). Thus, RPP8 can be induced during the course of basal resistance to $H$. arabidopsidis.

To determine whether other $R P P$ genes are responsive to the same stimuli as $R P P 8$, we assayed mRNA from endogenous Col alleles of $R P P 1$ and $R P P 4$ using gene-specific, semiquantitative PCR. RPPI had been previously reported as SA responsive (Shirano et al. 2002) but had not been tested for pathogen responsiveness. RPP4 expression in response to pathogens or SA had not been previously reported. For the RPPl assay, we designed primers against At3g44400, which is the probable ortholog of the RPPIA allele in the Wasselewskija ecotype, previously shown to provide resistance against three $H$. arabidopsidis isolates. The recognition function, if any, of At3g44400 has not been determined. For the RPP4 assay, we designed primers for At4g16860, which provides resistance to $H$. arabidopsidis Emwal (van der Biezen et al. 2002). Both genes re- sponded to Emco5 inoculation (Fig. 2D). RPP4 consistently responded to SA treatment, whereas the response of At $3 g 44400$ was weak and inconsistent. Shirano and colleagues (2002) previously reported SA induction of RPPl based on an RT-PCR assay with primers that likely amplify multiple members of the gene family. Thus, it is likely that other members of the RPPI family are more responsive to SA.

\section{W boxes in the $R P P 8$ promoter are necessary for basal and induced expression.}

As a starting point for identifying regulatory mechanisms mediating pathogen responsiveness of RPP8, we conducted database searches for candidate cis regulatory elements in the 679bp RPP8 promoter. Searches in the PLACE (Higo et al. 1999) and PlantCARE (Lescot et al. 2002) databases revealed three W boxes in this region, each with a 'stringent' consensus sequence of TTGACT (Eulgem et al. 2000). We named these elements $\mathrm{W}^{\mathrm{RPP} 8} \mathrm{~A}, \mathrm{~W}^{\mathrm{RPP} 8} \mathrm{~B}$, and $\mathrm{W}^{\mathrm{RPP} 8} \mathrm{C}$ (Fig. $1 \mathrm{~A}$ ). $\mathrm{W}^{\mathrm{RPP}} \mathrm{B}$ and $\mathrm{W}^{\mathrm{RPP} 8} \mathrm{C}$ are adjacent to each other as inverted repeats and are completely conserved in the 5 ' regions of RPPS-Col, HRT, RCYl, and $R P P 8$ from the closely related species Arabidopsis lyrata (not shown) (A. lyrata sequence provided by J. Bergelson). $\mathrm{W}^{\mathrm{RPP}} \mathrm{A}$ is conserved in all of the A. thaliana alleles but not in A. lyrata.

Because $\mathrm{W}$ boxes have been previously associated with pathogen and wound responsiveness (Rushton et al. 2002), we

A

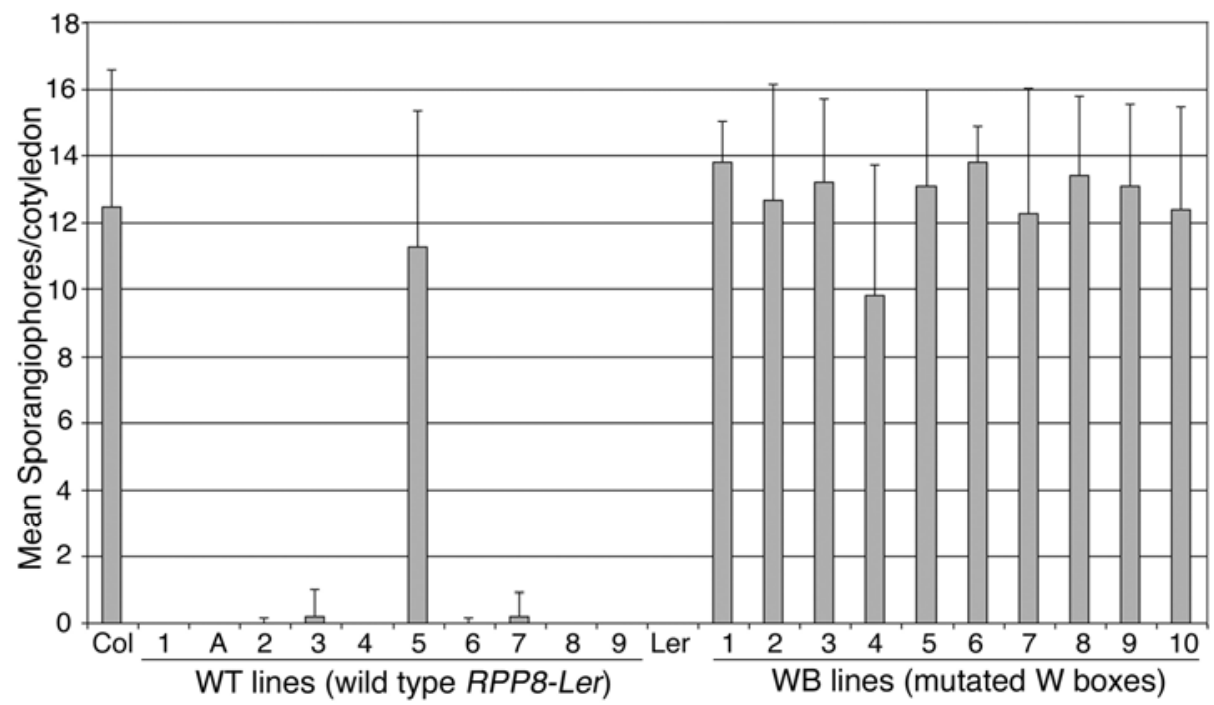

B

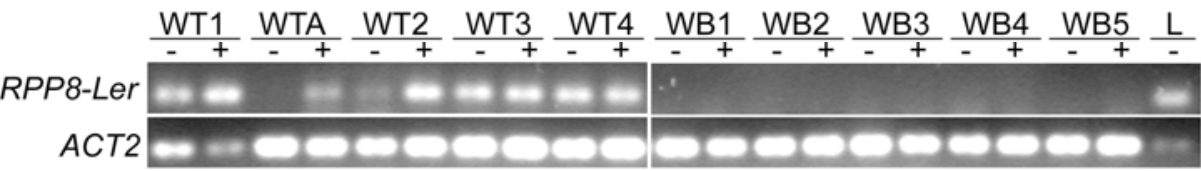

C
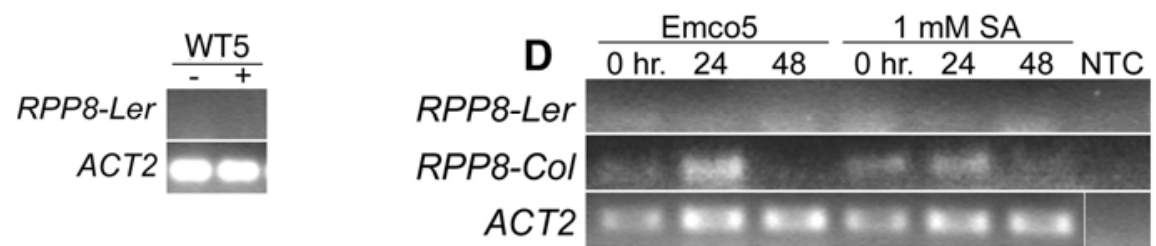

Fig. 4. Function and expression of an RPP8-Ler transgene in which $\mathrm{W}$ boxes 1, 2, and 3 have been mutated. A, Sporangiophore production in homozygous T3 populations, scored at 7 days after inoculation. Col and Ler are nontransgenic Columbia (susceptible) and Landsberg erecta (resistant) controls, respectively. Lines designated as WT contain a wild-type $R P P 8-L e r$ transgene. Lines designated as $\mathrm{WB}$ are independent lines of Col transformed with $\mathrm{W}^{\mathrm{RPP} 8} \mathrm{~A}$, $\mathrm{W}^{\mathrm{RPP} 8} \mathrm{~B}$, and $\mathrm{W}^{\mathrm{RPP} 8} \mathrm{C}$ were changed from TTGACT to TTGA $\underline{\mathrm{A}}$. Bars depict mean and standard deviation of sporangiophores per cotyledon, from $>40$ cotyledons scored per line. This experiment was performed twice, with similar results. B, Transcript levels from Col plants expressing wild-type RPP8-Ler (WT) or RPP8-Ler with the W box mutations (WB). mRNA was isolated from untreated plants (-) or at $48 \mathrm{~h}$ after infection with Emco5 (+). L designates a control polymerase chain reaction (PCR) of RPP8 from Landsberg RNA. C, Transcript levels from the WT5 line, containing a wild-type RPP8-Ler transgene that is not transcribed. D, Semiquantitative PCR of RPP8-Ler and RPP8-Col from the transgenic line WB5. 
tested the relevance of these $\mathrm{W}$ boxes to RPP8 transcription. We used site-directed mutagenesis to create a single promoter in which $\mathrm{W}^{\mathrm{RPP} 8} \mathrm{~A}, \mathrm{~W}^{\mathrm{RPP} 8} \mathrm{~B}$, and $\mathrm{W}^{\mathrm{RPP} 8} \mathrm{C}$ were changed from TTGA드 to TTGAAT. This substitution has been shown in three previous studies to abolish WRKY binding, based on gelshift assays (Du and Chen 2000; Kim and Zhang 2004; Yu et al. 2001). We replaced the wild-type promoter in the RPP8-Ler genomic clone (Fig. 1B) with the W-box triple-mutant promoter. This construct was designated WB and the corresponding wildtype clone (pRPP8, described by McDowell and associates [1998]) was designated WT.

To test the effect of WRKY mutations on RPP8-Ler expression and resistance to Emco5, we transformed Col-0 with constructs containing either the wild-type RPP8-Ler gene or the WB variant. T2 seed was collected from $56 \mathrm{WB}$ construct transformants and 19 WT transformants. Then, 7-day-old seedlings were sprayed with Emco5, and resistance was assessed 1 week later by counting sporangiophores on cotyledons. RPP8Ler-dependent resistance should segregate 3:1 resistant/susceptible in $\mathrm{T} 2$ populations, assuming a single transgenic locus. We observed this segregation ratio in 14 of 19 WT lines (data not shown). Four WT lines exhibited higher proportions of resistant plants, indicating multiple, unlinked transgene insertions. These lines were not analyzed further. One WT line (WT5) was fully susceptible, suggesting that the RPP8-Ler transgene in this line was silenced; this was later confirmed by RT-PCR (Fig. 4C). Significantly, all 56 WB lines did not segregate for resistance, and were as susceptible to Emco5 as untransformed Columbia (data not shown).

These phenotypes were confirmed in homozygous T3 populations developed from 10 independent lines containing each construct. Resistance was assayed in these populations by counting sporangiophores on $>40$ cotyledons from each line (Fig. 4A). As expected, 9 of $10 \mathrm{WT}$ lines demonstrated complete or almost complete resistance to Emco5 (Fig. 4A). The silenced line WT5 was fully susceptible, consistent with the absence of detectable RPP8-Ler transcript (Fig. 4C). Strikingly, all $10 \mathrm{Col}:$ WB lines were as susceptible as wild-type Col to Emco5. Thus, the W-box mutations completely abolish resistance mediated by RPP8-Ler.

We then tested RPP8-Ler transcript levels in five randomly selected WB T3 lines. RPP8-Ler mRNA was undetectable by gene-specific RT-PCR in either untreated or Emco5-challenged samples after 35 cycle of PCR amplification (Fig. 4B). However, mRNA was barely detectable in these lines after 40 cycles (not shown). A time-course analysis of three lines confirmed that transcript levels are barely detectable in unchallenged plants, as well as in response to Emco5 challenge and

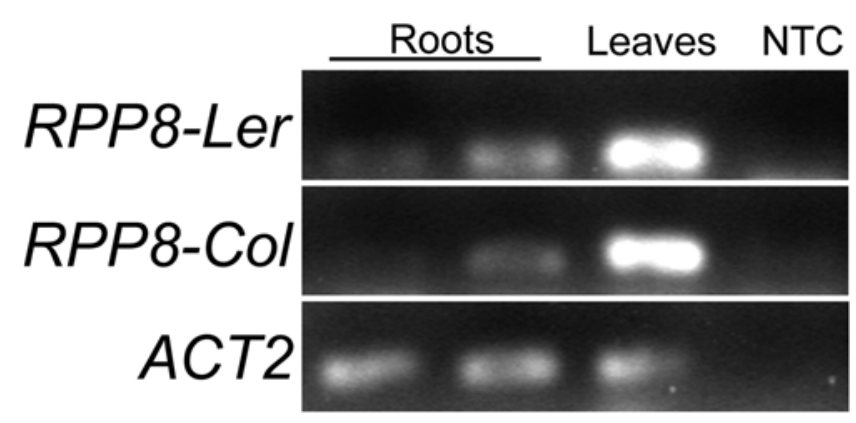

Fig. 5. $R P P 8$ transcript is present at higher levels in leaves than in roots. Gene-specific, semiquantitative reverse-transcription polymerase chain reaction of transgenic (RPPS-Ler) and endogenous (RPP8-Col) alleles of $R P P 8$, assayed in transgenic line WTA. Roots and leaves were collected from 3-week-old plants grown on vertical agar plates. Amplification products from two independently collected root samples are shown. NTC denotes no template control. treatment with SA (Fig. 4D and data not shown). Thus, W boxes and, presumably, one or more WRKY proteins are important factors for regulation of $R P P 8$ under optimal growth conditions as well as in response to pathogen attack.

\section{RPP8-Ler and RPP8-Col are transcribed}

at higher levels in leaves than in roots.

Little is known about the organ-specific expression patterns of $R P P$ genes. We observed strong Col::RPPS-LUC activity in leaves and inflorescence stems but no luciferase expression was apparent in roots (data not shown). To confirm the tissuespecific expression of RPP8-Ler and RPP8-Col, we examined transcript levels in the single-copy Col::RPP8-Ler line WTA. Allele-specific $R P P 8$ transcription was analyzed by semiquantitative RT-PCR with RNA from 3-week-old roots and leaves. RPP8-Ler and RPP8-Col transcripts were abundant in leaf tissue (Fig. 5). Both transcripts were detected at much lower levels in the roots. Consistent with this result, massively parallel signature sequencing (MPSS) (Meyers et al. 2004) detected RPP8-Col transcript in 21-day-old leaves (69 parts per million [ppm]) and inflorescences (27 ppm) but not in 21-day-old roots $(0 \mathrm{ppm})$. These data demonstrate that $R P P 8-C o l$ and $R P P 8$-Ler are expressed much more abundantly in leaves than in roots.

Global analysis of Arabidopsis NB-LRR gene expression.

We were interested in determining whether the pathogen responsiveness of the $R P P$ genes represents a general attribute of NB-LRR genes. To this end, we examined Arabidopsis NBLRR expression patterns in publicly available microarray data,

Table 1. Number of nucleotide-binding leucine-rich repeat (NB-LRR) genes or randomly selected genes induced by pathogen-relevant treatments, based on analysis of microarray data using Genevestigator

\begin{tabular}{lcc}
\hline & No. of genes induced twofold or more \\
\cline { 2 - 3 } Treatment & NB-LRR & Random \\
\hline Alternaria brassicicola & 5 & 4 \\
Agrobacterium tumefaciens & 14 & 18 \\
Botrytis cinerea & 6 & 10 \\
Erysiphe chicoracearum & 9 & 4 \\
E. orontii & 0 & 0 \\
Heterodera schachtii & 16 & 14 \\
Phytophthora infestans & 6 & 1 \\
Pseudomonas syringae & 28 & 8 \\
Chitin & 36 & 9 \\
Hydrogen peroxide & 13 & 8 \\
Ozone & 19 & 6 \\
Syringolin & 31 & 6 \\
Ethylene & 5 & 14 \\
Methyl jasmonate & 9 & 3 \\
Salicylic acid & 14 & 7.1 \\
Average & 14.1 & 6 \\
\hline
\end{tabular}

Table 2. Responsiveness of nucleotide-binding leucine-rich repeat (NBLRR) genes to pathogen-relevant treatments

\begin{tabular}{lcc}
\hline & \multicolumn{2}{c}{ No. of genes induced twofold or more } \\
\cline { 2 - 3 } No. of treatments & NB-LRR & Random \\
\hline 0 & 49 & 72 \\
1 & 17 & 29 \\
2 & 20 & 11 \\
3 & 16 & 3 \\
4 & 10 & 3 \\
5 & 8 & 3 \\
6 & 2 & 2 \\
7 & 2 & 1 \\
$>7$ & 0 & 0 \\
Total & 124 & 124 \\
\hline
\end{tabular}


using the Meta-Analyzer tool from the Genevestigator suite (Zimmermann et al. 2004, 2005). We queried responses of NB-LRR genes to eight pathogens, including the bacterial crown gall pathogen Agrobacterium tumefaciens, the bacterial leaf spot pathogen bacteria Pseudomonas syringae, the biotrophic powdery mildew fungi Erysiphe orontii and E. chicoracearum, the necrotrophic fungi Alternaria brassicicola and Botrytis cinerea, the late blight oomycete Phytophthora infestans, and the nematode Heterodera schachtii. We also examined responses to four small molecules that regulate defense responses (hydrogen peroxide, methyl jasmonate, ethylene, and SA), as well as two pathogen elicitors (chitin and syringolin), and one abiotic stressor (ozone) that triggers defense-like responses. Details about the design of these experiments, and corresponding references, are available through the Genevestigator site. We surveyed expression changes reported by 124 probe sets, which correspond to 133 NB-LRR genes (Supplementary Table 1). In all, 15 NB-LRR genes in the Col genome, including $R P P 8-\mathrm{Col}$, are not detected by any probe set on the Affymetrix $22 \mathrm{~K}$ chip, 18 probe sets detect transcripts from multiple genes, and 12 NB-LRR genes are detected by two probe sets. To simplify the discussion below, we consider each probe set as being equivalent to a single gene. For comparison, we examined expression changes in 124 probe sets corresponding to a list of Arabidopsis genes that was randomly generated using the Random ID List Generator in the Botany Array Resource (Toufighi et al. 2005). We also examined five probe sets corresponding to 'defense marker genes' that were previously documented as strongly pathogen responsive (EDS1, PAD4, ICS1, PDF1.2, and PR-1) (Thomma et al. 1998; Feys et al. 2001; Wildermuth et al. 2001).

Our analysis revealed significant variation in the responsiveness of NB-LRR genes to the 15 pathogen-relevant treatments. This is illustrated by the heat map of NB-LRR expression, and by variation in the numbers of NB-LRR genes induced by different treatments (Table 1). Accordingly, individual NB-LRR genes varied in the number and types of treatments to which they respond (Table 2). Of the 124 NB-LRR genes, 75 are upregulated by twofold or more in response to at least one pathogen-related treatment. By comparison, 52 of the randomly selected genes responded to one or more treatments. Of these, only 23 responded to two or more treatments, compared with 58 NB-LRR (two-proportion test, $P$ value $<0.001$ ). This distribution indicates a significant bias within the NB-LRR superfamily toward pathogen responsiveness. Similarly, the 15 treatments induced an average of 14.1 NB-LRR genes compared with an average of 7.1 random genes (Table 1). However, the NB-LRR genes appear significantly less pathogen responsive than the defense marker genes, which were induced twofold or higher by an average of 6.4 treatments (Supplementary Table 4). By comparison, the 124 NB-LRR genes were induced by an average of 1.7 treatments and the 124 random genes were induced by 0.85 treatments (Supplementary Tables 2 and 3). We conclude that NB-LRR genes tend to be more pathogen responsive than random genes but less responsive than canonical defense marker genes.

The same trends were apparent when we analyzed only the NB-LRR with a genetically defined resistance function (Supplementary Table 5). These genes vary significantly in their responses to the 15 treatments, and are induced twofold or more by an average of 1.67 treatments compared with 1.70 for the entire NB-LRR family. Thus, it is unlikely that our analysis of the entire NB-LRR family was skewed by a high proportion of NB-LRR pseudogenes or defeated alleles that are not under selection for optimal regulation. In general, the data from these microarray experiments is consistent with our observations and previous reports: SA induces $S N C 1, S S I 4$, and RPP4 (Shirano et al. 2002; Yang and Hua 2004). Some members of the RPPl family are weakly induced by SA, while others are not (Shirano et al. 2002).

Analysis of microarray data from experiments involving mutants revealed several possible regulatory connections that encompassed a significant proportion of NB-LRR genes (Supplementary Table 6). First, many NB-LRR genes are upregulated in the mpk4 mutant that disables a mitogen-activated protein (MAP) kinase which negatively regulates SA-dependent defenses (Brodersen et al. 2006). A similar effect is evident in the double mutant $m k k 1 / m k k 2$, which disables two functionally redundant MAP kinase kinases that act upstream of MPK4 (Qiu et al. 2008). These results highlight the capacity for broad upregulation of NB-LRR genes under defense-inducing conditions, at least in part by the SA pathway. The hormone ethylene likely also contributes to NB-LRR gene induction, because NB-LRR genes are broadly upregulated in the ctrl mutant (constitutive triple response) (Brodersen et al. 2006). The opposite effect was observed in the ABA hypersensitivity mutants ahg 1-1 and ahg3-1. Treatments of these mutants with exongenous ABA resulted in downregulation of many NB-LRR genes, suggesting that ABA can negatively regulate NB-LRR gene expression (Nishimura et al. 2007). Finally, NB-LRR gene activation is compromised in the flagellin receptor mutant $f l s 2$, substantiating a connection between NB-LRR activation and PAMP-triggered immunity.

\section{Analysis of cis elements in NB-LRR gene promoters.}

We used the Promomer tool in the Botany Array Resource (Toufighi et al. 2005) to determine whether W boxes or other known cis elements are statistically overrepresented in NB-LRR gene promoters. Promomer uses an enumerative approach (Ohler and Niemann 2001), in which it searches for all possible oligomers with a user-defined length, and evaluates the statistical significance of each oligomer's frequency in the data set compared with a background model constructed from an equivalent number of randomly selected Arabidopsis promoters. We searched for overrepresented 4- or 5-bp motifs that were present in at least $75 \%$ of the promoters from $148 \mathrm{NB}$ LRR genes. Promomer identified 69 four-mers and 52 fivemers with $P$ values of 0.05 or lower (Supplementary Tables 7 and 8). We queried the PLACE database (Higo et al. 1999) with these 131 elements to identify matches to previously defined cis regulatory sequences. Only two were found: TGAC and TTGAC, both of which match the 'stringent' W-box consensus TTGAC(C/T) (Eulgem et al. 2000). Both of these elements were identified by Promomer as overrepresented at $P=$ 0.005. In addition, manual examination revealed WRKY core sequences in the reverse orientation (TGCA, $P=0.001$; TGCAA, $P=0.05)$. The reverse orientation can function as a WRKY-binding site but is not detected by PLACE. Similarly, a search using the Data Mining tool in the ATHENA analysis suite identified TTGAC $(\mathrm{C} / \mathrm{T})$ as the only known cis element that is significantly enriched in the NB-LRR promoters $(P<$ $10^{-5}$ ) (O'Connor et al. 2005). This overrepresentation suggests that WRKY proteins regulate a significant number of NB-LRR genes.

\section{DISCUSSION}

The results from this study demonstrate that $R P P$ genes of the CC- and TIR-NB-LRR gene superfamilies are upregulated during defense against Hyaloperonospora arabidopsidis and in response to exongenous SA. Other pathogen-responsive NBLRR genes include Arabidopsis RPP7 (Eulgem et al. 2007), rice $\mathrm{Xa1}, \mathrm{Xa3}$, and $\mathrm{Xa27}$ against bacterial blight (Cao et al. 2007; Yoshimura et al. 1998); rice Pib against rice blast (Wang 
et al. 2001); barley Mla6 and Mla13 against powdery mildew (Halterman et al. 2003); the tobacco $N$ gene against Tobacco mosaic virus (Levy et al. 2004); and the Solanum bulbocastanum $R B$ gene against $P$. infestans (Kramer et al. 2009). These genes vary significantly with respect to external cues that provoke upregulation. For example, $\mathrm{Xa1}, \mathrm{Xa3}$, and $\mathrm{Pib}$ are responsive to multiple stimuli, including compatible and incompatible pathogens, environmental cues, and host genetic background and developmental stage (Cao et al. 2007; Wang et al. 2001; Yoshimura et al. 1998). In contrast, barley Mla6 and Mlal exhibit a very specific response. Both genes are induced only during resistance triggered by the cognate pathogen. In other words, Mla6 is induced during Mla6-dependent resistance but not during Mla13-dependent resistance (Halterman et al. 2003). The converse is true for Mla13. RPP8 is upregulated in response to multiple avirulent $H$. arabidopsidis isolates and by wounding, indicating that that this gene is connected to multiple regulatory pathways.

Our global analysis of NB-LRR gene expression generalized the variability described in the previous paragraph. A large percentage of NB-LRR genes responded to at least one of the pathogen-relevant treatments that we surveyed. This argues against the simple hypothesis that most $R$ genes are "constitutively' expressed. However, the responsive NB-LRR genes varied widely in terms of the number and types of treatments to which they responded. Therefore, it is unlikely that a single regulatory pathway mediates $R$-gene induction. Moreover, 49 of 124 NB-LRR genes were not induced by any of the treatments at levels of twofold or higher, arguing against the hypothesis that all $R$ genes are pathogen responsive. In sum, our global analysis is consistent with trends apparent from previous characterizations of individual $R$ genes: some $R$ genes are induced by a variety of stimuli, some display very specific responses, and others appear to be pathogen nonresponsive. Similar conclusions were reached by Tan and associates (2007) in a global examination of NB-LRR genes using data from MPSS and microarrays that reported responses to SA and to Pseudomonas syringae.

Why might such variability in $R$-gene regulation have evolved? As mentioned in the introduction, genetic and molecular studies indicate that $R$ genes have a very narrowly defined threshold of expression, below which resistance is not optimally activated. Conversely, deleterious effects of overexpressed $R$ genes imply a second threshold, above which $R$ genes cannot be expressed without imparting a severe growth penalty to the plant. Perhaps evolution has driven $R$ genes to be expressed at very low basal levels, ideally below thresholds for deleterious side effects. Pathogen-induced upregulation could then transiently elevate $\mathrm{R}$ protein abundance above the threshold necessary for a rapid, robust resistance response. The absolute levels of these two thresholds might vary from gene to gene and perhaps from allele to allele. 'Weak' $R$ alleles (e.g., encoding proteins with weak affinity for the ligand) might have a relatively high threshold for efficient resistance compared with strong alleles. Conversely, $R$ alleles that autoactivate, or provide inappropriate recognition of 'self' or other cues, might impart a penalty even when expressed at low levels (one potential example is RPM1) (Tian et al. 2003). Hence, the importance of upregulation may vary between NB-LRR genes and alleles.

Similarly, the importance of upregulation may change over the evolutionary lifespan of any given $R$ gene or allele. For example, natural selection might favor acquisition of upregulation to 'boost' a newly evolved, weak resistance specificity. Upregulation may then become superfluous as the $R$ gene evolves toward optimality (e.g., strong ligand binding). Conversely, natural selection could act to reduce upregulation or basal expression if the encoded $\mathrm{R}$ protein evolves deleterious background activity. This may explain why some $R$ genes are upregulated to varying degrees during defense induction while others are pathogen nonresponsive. We also note that several studies have provided evidence for regulation of NB-LRR genes at epigenetic, post-transcriptional (i.e., RNA silencing) and post-translational levels (Bieri et al. 2004; Boyes et al. 1998; Li et al. 2007, 2009; Shirasu and Schulze-Lefert 2003; Schulze-Lefert 2004; Yi and Richards 2007). Thus, it appears that plants can regulate $R$ gene or protein activity at multiple levels and that at least some $R$ genes are under complex regulation. From this observation, it follows that multiple regulatory mechanisms could be recruited during evolution to finetune the expression of individual genes.

How might $R$-gene upregulation benefit defense network functionality? Upregulation could enhance $R$-gene resistance by establishing a positive feedback loop. Positive feedback in cellular regulatory networks can be advantageous in situations where 'all-or-nothing decisions' must be made from weak, noisy input signals (Stelling et al. 2004). Upregulation of $R$ genes could provide for a more robust response, particularly in situations where recognition is weak, the $R$ locus is heterozygous, or the defense network is hampered by pathogen effectors or unfavorable environmental conditions (Bradeen et al. 2009; Chang et al. 2004; Kramer et al. 2009; Yang and Hua 2004). As noted by Kramer and colleagues (2009), the timing of peak transcript abundance could be particularly important for effective resistance at early stages of the interaction. Wang and colleagues (2001) have proposed that $R$ genes are subject to 'anticipatory control' by cues indicating favorable conditions for infection (e.g., wounding). This responsiveness to wounding and environmental cues might be mediated by ethylene or ABA.

Upregulation of $R$ genes could contribute to basal resistance or systemic acquired resistance by broadening the spectrum of potential recognition, as proposed by Shah and colleagues (2003). Consistent with this hypothesis, NB-LRR genes are overrepresented among genes induced by the bacterial PAMP flagellin (Navarro et al. 2004; Zipfel et al. 2004). This connection is further substantiated by microarray analysis of the flg22-treated fls 2 mutants. Accordingly, RPPS-Col is induced during a compatible interaction with Emco5 (Fig. 4C), suggesting that its regulation is linked to basal resistance.

Is pathogen-induced upregulation of NB-LRR genes functionally relevant for specific recognition of the cognate pathogens? We note that the magnitude of $H$. arabidopsidis-induced RPP8 upregulation is modest (generally two- to threefold) when quantified on a whole-leaf level. However, the Arabidopsis-H. arabidopsidis interaction is spatially localized in resistant plants. The majority of cells in an infected leaf do not undergo a hypersensitive response even when high inoculum concentrations are applied (Eulgem et al. 2004; McDowell et al. 1998). Thus, RT-PCR assays of homogenized leaves likely underestimate RPP8 induction at the infection site if a strong signal from cells at infection sites is diluted by a weak signal from distal cells. Accordingly, Col::RPP8-LUC leaves inoculated with a single drop of Emco5 spores displayed strong luciferase activity in the immediate vicinity of the drop and weak activity elsewhere (data not shown). It is relevant that $R P P 8, R P P 4$, and $R P P 1$ exhibit incomplete genetic dominance, in which limited vegetative growth and asexual sporulation are permitted when these genes are hetero- or hemizygous (Bieri et al. 2004; Holt et al. 2005; McDowell et al. 1998; Reignault et al. 1996; van der Biezen et al. 2002). This dose dependency indicates that twofold changes in expression levels are functionally relevant. In addition, the efficiency of resistance provided by $H R T, X a 3$, and $R B$ is clearly correlated with gene copy number and transcript levels (Bradeen et al. 2009; Cao et 
al. 2007; Chandra-Shekara et al. 2004; Kramer et al. 2009). These examples indicate that upregulation is functionally relevant for resistance. This question could be further addressed by replacing endogenous promoters of these genes with heterologous promoters that provide equivalent basal expression but are not pathogen or SA inducible, and then testing whether these pathogen-nonresponsive transgenes are functionally compromised.

The pathways that regulate pathogen-responsive NB-LRR genes have not been well defined. In this regard, it is interesting that exogenous SA induces $H R T$ and multiple $R P P$ genes, because SA is commonly thought to act downstream of R proteins. Other SA-responsive genes include rice $P i b$ and the resistance gene analogs SNC1 and SSI4 from Arabidopsis. In addition, HRT, RPP4, RPP1, and other NB-LRR genes are transcriptionally induced when oleic acid levels in the plant are decreased by mutations in biosynthetic genes or by exogenous application of glycerol (Chandra-Shekara et al. 2007; Venugopal et al. 2009). Interestingly, this inducibility is suppressed by mutations in functionally redundant pathways that require SA and EDS1, respectively. These data are consistent with a model in which SA and EDS1 regulate transcription of some NB-LRR genes. In addition, RPP8-dependent resistance to $H$. arabidopsidis Emco5 is significantly suppressed in an NahG/eds 1 background. It is not clear whether this suppression of resistance is due to an effect on $R P P 8$ transcript levels or due to loss of SA- and EDS1-dependent functions that are downstream of RPP8.

A model for $R P P 8$ transcriptional regulation is outlined in Figure 6. First, we propose that RPP8 and other SA-responsive NB-LRR genes are regulated by an SA- and EDS1-dependant positive-feedback loop. A similar feedback mechanism has been proposed for SSI4 and SNC1 (Shirano et al. 2002; Shah 2003; Xiao et al. 2003). It is also likely that $R P P 8$ is regulated by NPR1, because $R P P 8$ was identified in a screen for transcriptional targets of NPR1 (Wang et al. 2005). Finally, it is
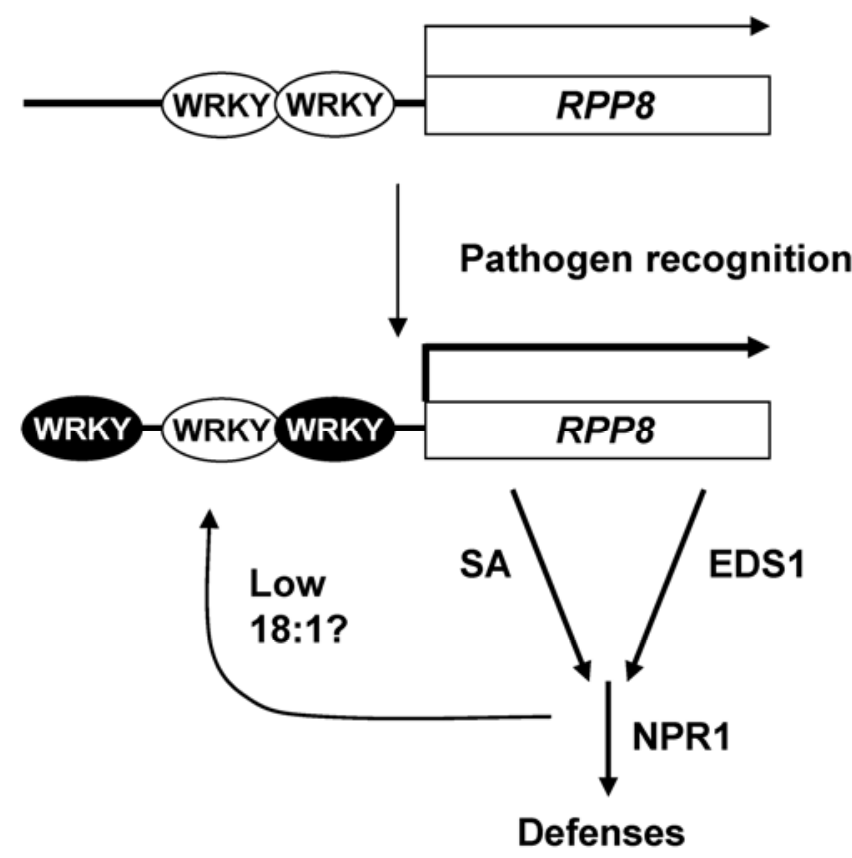

Fig. 6. Working hypothesis for transcriptional regulation of RPP8. Basal $R P P 8$ expression is positively regulated by one or more WRKY proteins that associate with one or more of the three $\mathrm{W}$ boxes in the RPP8 promoter. Pathogen recognition activates the salicylic acid and glycerol signaling pathways, leading to qualitative or quantitative changes in the $R P P 8$-associated WRKY pool which, in turn, leads to elevated RPP8 expression. probable that $R P P 8$ is responsive to oleic acid, because the $R P P 8$ and $H R T$ promoters are almost identical.

Nothing is known about the cis elements or trans factors that regulate NB-LRR gene transcription. Our data demonstrate that one or more of the three $\mathrm{W}$ boxes in the RPP8 promoter are important for transcription. W boxes have previously been posited as important regulatory elements in genes that encode redox components, transcriptional regulators of defense, and antimicrobial genes, indicating that WRKYs play varied roles in coordinating defense responsiveness (Eulgem and Somssich 2007; Pandey and Somssich 2009). The importance of $\mathrm{W}$ boxes for $R P P 8$ regulation, along with the overrepresentation of $\mathrm{W}$ boxes in NB-LRR promoters, indicate that the sphere of WRKY influence extends to the very top of the defense cascade. The exact roles of individual RPP $8 \mathrm{~W}$ boxes and the identity of cognate DNA-binding proteins remain to be determined. It is possible that the mutations in the RPP8-Ler $\mathrm{W}$ boxes affect binding by a non-WRKY regulatory protein. We consider this unlikely because $\mathrm{W}$ boxes have not previously been previously associated with any type of protein other than WRKYs.

Because $\mathrm{W}$ boxes have been predominantly associated with pathogen-induced transcriptional upregulation, we expected that the $\mathrm{W}$ box mutations would primarily affect $R P P 8$ upregulation in response to Emco5 or SA. However, our experiments indicate that WRKYs are important regulators under optimal growth conditions as well as defense-inducing conditions. A previous mutational analyses of the NPR1 promoter yielded similar results, in which $\mathrm{W}$ box mutations abolished both basal and SA-inducible transcription (Yu et al. 2001). Therefore, it will be of interest to test whether RPPS and NPRI are regulated by the same WRKYs.

How might WRKYs regulate both basal and induced transcription? One model follows from analysis of WRKY binding of the parsley WRKY1 promoter (Turck et al. 2004). The authors used chromatin immunoprecipitation to demonstrate that WRKY1 W boxes are continuously occupied by WRKYs but the composition of these WRKYs changes dynamically under defense-inducing conditions. Accordingly, we propose that one or more WRKY proteins is responsible for basal expression of $R P P 8$, and that pathogen-induced upregulation results from quantitative or qualitative changes in the WRKY population that are driven by SA signaling (Fig. 6). Another, nonexclusive possibility is that individual $\mathrm{W}$ boxes in the $R P P 8$ promoter have distinct roles in $R P P 8$ regulation. For example, the $\mathrm{W}^{\mathrm{RPP}}{ }^{\mathrm{B}}-\mathrm{W}^{\mathrm{RPP}} \mathrm{C}$ cluster might be responsible for maintaining basal $R P P 8$ expression while $\mathrm{W}^{\mathrm{RPP} 8} \mathrm{~A}$ might mediate upregulation. These hypotheses could be addressed by mutation of individual $\mathrm{W}$ boxes in the RPP8 promoter and analysis of WRKYs that bind these elements.

\section{MATERIALS AND METHODS}

Plant cultivation and treatment.

Seed were sown in Sunshine Mix no. 1 (Sungro Horticulture, Seba Beach, Canada) and stratified at $4^{\circ} \mathrm{C}$ for at least 2 days. Plants were grown in a Percival Scientific CU-36L4 growth chamber (Boone, IA, U.S.A.) with light intensities of approximately 50 microEinsteins, under 14 -h days at $23^{\circ} \mathrm{C}, 10-\mathrm{h}$ nights at $21^{\circ} \mathrm{C}$, and ambient humidity. After treatment, all plants were covered with a clear plastic dome to maintain high humidity and transferred to a Percival Scientific CU-36L4 growth chamber at ambient humidity, with light intensities of approximately 85 microEinsteins, under 8 -h days at $20^{\circ} \mathrm{C}$ and 16 -h nights at $18^{\circ} \mathrm{C}$. Leaf and root tissues for the tissue-specific expression assay (Fig. 5) were grown on germination medium plates prepared with Phytagel (Sigma-Aldrich, St. Louis) 
at $1.95 \mathrm{~g} /$ liter and Murashige and Skoog vitamin solution to $1 \times$ final concentration (Sigma-Aldrich). Sterilized seed were sown horizontally across the top of rectangular plates. The plates were stratified at $4{ }^{\circ} \mathrm{C}$ for 2 days and grown in a Percival Scientific CU-36L4 growth chamber at ambient humidity, with light intensities of approximately 110 microEinsteins, under 16-h days at $23^{\circ} \mathrm{C}$ and 8 -h nights at $21^{\circ} \mathrm{C}$ for 3 weeks. Plates were inclined so that roots grew downward along the media surface. Leaf tissues were removed and collected first to avoid contamination of root tissue.

\section{Plasmid constructs.}

pRPP8-LUC was constructed as follows. A 5.5-kb EcoRI fragment containing RPP8-Ler was initially subcloned from pRPP8 (McDowell et al. 1998) into pBluescript SK(+) to create pJGJ329. RPP8 was fused to $L U C$ by inserting a $L U C$ NOS cassette into pJGJ329 as a BamHI-SalI fragment to create pCG1. This step resulted in the removal of a 1-kb BamH1-Sal1 fragment from pCG1 that contained the $3^{\prime}$ end of the RPP8 gene, including $500 \mathrm{bp}$ of $3^{\prime}$ coding sequence. This segment of the RPP8 coding region was amplified from pJGJ329 by PCR, using primers with restriction sites that enabled insertion of this segment as a SnaBI-NarI fragment into pCG1 to restore a full-length $R P P 8$ coding sequence translationally fused to $L U C$ (pBW35). The RPPS-LUC-NOS cassette was excised as a Not $1 / X h o 1$ fragment and treated with Klenow DNA polymerase. The blunt-ended fragment was then inserted into the Sma1 site of pCAMBIA3000 to create pBW37, which was renamed as pRPP8-LUC.

An analogous strategy was used to create pRPH8A-LUC. RPH8A was inserted as a BamH1 fragment from p9L9 (McDowell et al. 1998) into pJGJ184 to create an RPH8ALUC-NOS fusion in which 500 bp of $3^{\prime}$ coding sequence was deleted (pCG2). The $3^{\prime}$ coding sequence was amplified by PCR and inserted to create a precise fusion to $L U C$ as described above (pBW35). The RPH8A-LUC-NOS cassette was then moved to pCAMBIA3300 as described above to create pBW40, which was renamed as pRPH8A-LUC.

The RPP8 W boxes were mutagenized using the Quikchange procedure (Stratagene). Primers for mutagenesis (Supplementary Table 9) were designed with the Stratagene ( $\mathrm{La}$ Jolla, CA, U.S.A. )online tool. Polyacrylamide gel electrophoresis-purified primers were ordered from IDT (Coralville, IA, U.S.A.) and were used with the Quikchange II XL sitedirected mutagenesis kit as per the manufacturer's instructions. The template plasmid was pJGJ329. W-boxes were individually mutated in the following order: $\mathrm{W}^{\mathrm{RPP} 8} \mathrm{~B}, \mathrm{~W}^{\mathrm{RPP} 8} \mathrm{C}$, and $\mathrm{W}^{\mathrm{RPP}} \mathrm{A}$ (Fig. 1). The final $W B$ promoter was excised as a $B s m \mathrm{BI} / X m a \mathrm{I}$ fragment, and was used to replace the corresponding wild-type BsmBI/XmaI fragment in the original pJGJ329 construct. This strategy avoided introduction of unwanted mutations into the RPPS-Ler coding region over the course of mutagenesis. This construct was named pTJB004. The entire RPP8-Ler gene was then cloned into the pBAR1 binary plasmid (McDowell et al. 1998) using EcoRI and $X m a I$ sites. This resulted in a construct that was identical to the wild-type RPP8-Ler construct (pRPP8) (McDowell et al. 1998), except for the three $\mathrm{W}$ box mutations.

All PCR fragments and ligation sites in the above constructs were confirmed by sequencing.

\section{Plant transformation.}

Constructs were transformed into the Agrobacterium strain GV3101 by electroporation. Plants were transformed using the floral dip protocol (Clough and Bent 1998). BASTA (glufosinate-ammonium) selection was performed as previously described (McDowell et al. 1998).
Pathogen challenge assays, chemical treatments, and wounding.

$H$. arabidopsidis pathogen strains were propagated weekly on genetically susceptible Arabidopsis, as described (McDowell et al. 2000). RPP8-LUC induction by $H$. arabidopsidis was measured by challenging Col::RPP8-LUC plants with Emco5 $\left(5 \times 10^{4}\right.$ or $5 \times 10^{5}$ conidiosporangia $\mathrm{ml}^{-1}$ in distilled water, sprayed to the point of imminent runoff). Resistance in Col:WT and Col::WB constructs (Fig. 4) was tested by inoculating 7-day-old transgenic seedlings with Emco5 at $5 \times 10^{4}$ conidiosporangia $\mathrm{ml}^{-1}$. H. arabidopsidis reproduction was determined by visual assessment of sporangiophore production at 7 days post infection in a manner similar to that of McDowell and associates (2000): real numbers of sporangiophores per cotyledon were counted on cotyledons that supported 0 to 10 sporangiophores. Cotyledons with 11 or more sporangiophores were classified as exhibiting 'heavy' sporulation and assigned values of 15 . To assay potential chemical inducers, Col::RPP8$L U C$ plants were sprayed to the point of imminent runoff with $1 \mathrm{mM}$ SA (Sigma-Aldrich), $250 \mu \mathrm{M}$ BTH (provided by Syngenta, Research Triangle Park, NC, U.S.A.), $50 \mathrm{mM}$ methyl jasmonate (Sigma-Aldrich), $20 \mathrm{mM}$ 2,4D (Sigma-Aldrich), $150 \mu \mathrm{M}$ of the ROI generator rose bengal (Sigma-Aldrich), or $1 \%$ hydrogen peroxide. All solutions were dissolved in water. Wound assays were performed on rosette leaves either by cutting incisions with scissors or by crushing leaf margins with flat forceps, once on either side of the central leaf vein.

\section{Luciferase assays.}

Luciferase expression was assayed in plants individually grown in 2-in.-wide pots. Three to five plants from each line were assayed per treatment in each experiment. Plants were sprayed with a solution of $1 \mathrm{mM}$ luciferin (Biosynth $\mathrm{AG}$, Staad, Switzerland) and $0.01 \%$ Triton-X100 (Fisher Scientific, Fair Lawn, NJ, U.S.A.) and were incubated at room temperature for $20 \mathrm{~min}$ to allow the substrate to enter plant tissues. Photon emission was measured for 20 min using a Hamamatsu VIM-50 imaging system (Hamamatsu Corp. USA, Bridgewater, NJ, U.S.A.). Because the camera is able to detect a low level of infrared emission (so-called 'heat' photons), a pot of soil was assayed in each experiment to estimate background. Background levels of emission were subtracted from the values depicted in Figure 2. Luciferase activity was quantitatively measured by using gravity mode during photon counting with the ARGUS 50 software (Hamamatsu Corp.). All quantitative measurements used a 100-by-100-pixel square area that was sufficiently large to include the entire rosette leaf surface area. Qualitative images of luciferase activity were generated by superimposing slice mode photon-counting images upon the corresponding reflected-light image using the ARGUS-50 software. The luciferase overlays were adjusted to a bit range of three to five. This setting generally eliminated background photon activity over the soil. Initial luciferase activity $(0 \mathrm{~h})$ was measured immediately before treatment. All plants were initially assayed and treated in the morning (7:30 to 10:00 a.m.). Wounded plants were sprayed with luciferin and imaged before wounding $(0 \mathrm{~h})$, and were imaged for three consecutive hours after wounding without extra luciferin to monitor rapid changes in luciferase activity. All other time points were imaged after plants were sprayed with luciferin.

\section{cDNA preparation and RT-PCR.}

Total RNA was isolated using the Aurum RNA kit (Bio-Rad, Hercules, CA, U.S.A.) or Tri Reagent (Sigma-Aldrich). RNA quality was analyzed by spectrophotometry and by electrophoresis on a denaturing agarose gel. RNA was treated with the DNA-free DNase kit or the TURBO DNA-free DNase kit 
(Ambion, Austin, TX, U.S.A.), as the per manufacturer's recommendation for 'rigorous treatment.' First-strand cDNA was synthesized with Superscript II reverse transcriptase (Invitrogen, Carlsbad, CA, U.S.A.) or the Omniscript Reverse Transcription kit (Qiagen, Basel, Switzerland), using RNase Out recombinant ribonuclease inhibitor (Invitrogen) and oligo(dT)12-18 (Invitrogen) as per the manufacturer's recommendation. Samples were tested for genomic DNA contamination by PCR with the ACT2 primers, which span an 86-bp intron.

Quantitative PCR was performed using Taqman probes from Applied Biosystems (Foster City, CA, U.S.A.). Primers and probes for ACT2, RPP8-Ler, PR-1, and RPP8-Col were designed using Primer Express software (version 1.5; Applied Biosystems) and synthesized by IDT. Applied Biosystems Taqman Universal PCR Master Mix and MicroAmp optical 96-well reaction plates with optical adhesive covers were used for real-time PCR reactions. Measurements were made in an ABI PRISM 7700 Detection System. The threshold of each probe was kept constant to ensure consistent results between plates. RPP8-Ler was normalized to ACT2 for each sample, as described by Halterman and associates (2003). Data were analyzed in Microsoft Excel. Semiquantitative PCR was performed using the same primers used for real-time PCR. ACT2 was used as a control for equal cDNA loading. PCR conditions for $A C T 2$ and $R P P 8$ are as follows: $94^{\circ} \mathrm{C}$ for $3 \mathrm{~min}$; followed by 28 cycles of $94^{\circ} \mathrm{C}$ for $15 \mathrm{~s}, 60^{\circ} \mathrm{C}$ for $15 \mathrm{~s}$, and $72^{\circ} \mathrm{C}$ for 30 $\mathrm{s}$; and a 10 -min final extension time at $72^{\circ} \mathrm{C}$.

\section{Analysis of NB-LRR expression using Genevestigator.}

A list of 148 annotated NB-LRR genes was complied from the 'Functional and Comparative Genomics of Disease Resistance Gene Homologs (NIBLRRS)' project website in R. Michelmore's lab at the University of California, Davis (Meyers et al. 2003). We then compiled a list of 124 probe sets from the Affymetrix 22K chip corresponding with 133 genes. These probe sets were analyzed with the Meta-Analyzer tool in Genevestigator, with Stress Response, Stimulus, or Mutation options, using data from the ' $22 \mathrm{~K}$ ' chip, wild-type, highquality arrays. Ratios and color codes were imported into Excel by copying and pasting. Two proportion tests were performed using MINITAB (release 14.13; Minitab Inc, State College, PA, U.S.A.).

\section{ACKNOWLEDGMENTS}

This research was supported by grants from the United States Department of Agriculture, National Research Initiative (02-35319 to J. M McDowell), the National Institutes of Health (GM62352 to J. M. McDowell and J. G. Jelesko), National Science Foundation (IOS-0744875 to J. M. McDowell), Hatch grant funding (J. M. McDowell), and a Summer Undergraduate Research Fellowship from the American Society of Plant Biologists (N. D. Mammarella). A BAC clone containing the RPP8 gene was provided by the Arabidopsis Biological Resource Center, Ohio State University. We thank J. Bergelson (University of Chicago) for sharing the $A$. lyrata RPP8 promoter sequence, R. Dietrich (Syngenta, Research Triangle Park, NC, U.S.A.) for the gift of BTH, and anonymous reviewers for their helpful comments on the manuscript.

\section{LITERATURE CITED}

Ayliffe, M. A., Frost, D. V., Finnegan, E. J., Lawrence, G. J., Anderson, P. A., and Ellis, J. G. 1999. Analysis of alternative transcripts of the flax L6 rust resistance gene. Plant J. 17:287-292.

Bendahmane, A., Farnham, G., Moffett, P., and Baulcombe, D. C. 2002. Constitutive gain-of-function mutants in a nucleotide binding site-leucine rich repeat protein encoded at the Rx locus of potato. Plant J. 32:195-204.

Bieri, S., Mauch, S., Shen, Q. H., Peart, J., Devoto, A., Casais, C., Ceron, F., Schulze, S., Steinbiss, H. H., Shirasu, K., and Schulze-Lefert, P. 2004. RAR1 positively controls steady state levels of barley MLA resis- tance proteins and enables sufficient MLA6 accumulation for effective resistance. Plant Cell 16:3480-3495.

Botella, M. A., Coleman, M. J., Hughes, D. E., Nishimura, M. T., Jones, J. D. G., and Somerville, S. C. 1997. Map positions of 47 Arabidopsis sequences with sequence similarity to disease resistance genes. Plant J. 12:1197-1212.

Boyes, D. C., Nam, J., and Dangl, J. L. 1998. The Arabidopsis thaliana RPM1 disease resistance gene product is a peripheral plasma membrane protein that is degraded coincident with the hypersensitive response. Proc. Natl. Acad. Sci. U.S.A. 95:15849-15854.

Bradeen, J. M., Iorizzo, M., Mollov, D. S., Raasch, J., Kramer, L. C., Millett, B. P., Austin-Phillips, S., Jiang, J., and Carputo, D. 2009 Higher copy numbers of the potato RB transgene correspond to enhanced transcript and late blight resistance levels. Mol. Plant-Microbe Interact. 22:437-446.

Brodersen, P., Petersen, M., Nielsen, H. B., Zhu, S., Newman, M.-A., Shokat, K. M., Rietz, S., Parker, J., and Mundy, J. 2006. Arabidopsis MAP kinase 4 regulates salicylic acid- and jasmonic acid/ethylenedependent responses via EDS1 and PAD4. Plant J. 47:532-546.

Cao, Y., Ding, X., Cai, M., Zhao, J., Lin, Y., Li, X., Xu, C., and Wang, S. 2007. The expression pattern of a rice disease resistance gene $x a 3 / x a 26$ is differentially regulated by the genetic backgrounds and developmental stages that influence its function. Genetics 177:523-533.

Chandra-Shekara, A. C., Navarre, D., Kachroo, A., Kang, H. G., Klessig, D., and Kachroo, P. 2004. Signaling requirements and role of salicylic acid in HRT- and rrt-mediated resistance to Turnip crinkle virus in Arabidopsis. Plant J. 40:647-659.

Chandra-Shekara, A. C., Venugopal, S. C., Barman, S. R., Kachroo, A., and Kachroo, P. 2007. Plastidial fatty acid levels regulate resistance gene-dependent defense signaling in Arabidopsis. Proc. Natl. Acad. Sci. U.S.A. 104:7277-7282.

Chang, J. H., Goel, A. K., Grant, S. R., and Dangl, J. L. 2004. Wake of the flood: Ascribing functions to the wave of type III effector proteins of phytopathogenic bacteria. Curr. Opin. Microbiol. 7:11-18.

Chen, W., Provart, N. J., Glazebrook, J., Katagiri, F., Chang, H. S., Eulgem, T., Mauch, F., Luan, S., Zou, G., Whitham, S. A., Budworth, P. R., Tao, Y., Xie, Z., Chen, X., Lam, S., Kreps, J. A., Harper, J. F., SiAmmour, A., Mauch-Mani, B., Heinlein, M., Kobayashi, K., Hohn, T., Dangl, J. L., Wang, X., and Zhu, T. 2002. Expression profile matrix of Arabidopsis transcription factor genes suggests their putative functions in response to environmental stresses. Plant Cell 14:559-574.

Chisholm, S. T., Coaker, G., Day, B., and Staskawicz, B. J. 2006. Hostmicrobe interactions: Shaping the evolution of the plant immune response. Cell 124:803-814.

Clough, S. J., and Bent, A. F. 1998. Floral dip: A simplified method for Agrobacterium-mediated transformation of Arabidopsis thaliana. Plant J. 16:735-743.

Collier, S. M., and Moffett, P. 2009. NB-LRRs work a "bait and switch" on pathogens. Trends Plant Sci. 14:521-529.

Collins, N., Drake, J., Ayliffe, M., Sun, Q., Ellis, J., Hulbert, S., and Pryor, T. 1999. Molecular characterization of the maize Rp1-D rust resistance haplotype and its mutants. Plant Cell 11:1365-1376.

Cooley, M. B., Pathirana, S., Wu, H. J., Kachroo, P., and Klessig, D. F. 2000. Members of the Arabidopsis HRT/RPP8 family of resistance genes confer resistance to both viral and oomycete pathogens. Plant Cell 12:663-676.

Dangl, J. L., and McDowell, J. M. 2006. Two modes of pathogen recognition by plants. Proc. Natl. Acad. Sci. U.S.A. 103:8575-8576.

Delledonne, M., Xia, Y., Dixon, R. A., and Lamb, C. 1998. Nitric oxide functions as a signal in plant disease resistance. Nature 394:585-588.

Delledonne, M., Zeier, J., Marocco, A., and Lamb, C. 2001. Signal interactions between nitric oxide and reactive oxygen intermediates in the plant hypersensitive disease resistance response. Proc. Natl. Acad. Sci. U.S.A. 98:13454-13459.

Dong, X. 2004. NPR1, all things considered. Curr. Opin. Plant Biol. 7:547-552.

Du, L., and Chen, Z. 2000. Identification of genes encoding receptor-like protein kinases as possible targets of pathogen- and salicylic acidinduced WRKY DNA-binding proteins in Arabidopsis. Plant J. 24:837847.

Durner, J., Wendehenne, D., and Klessig, D. F. 1998. Defense gene induction in tobacco by nitric oxide, cyclic GMP, and cyclic ADP-ribose. Proc. Natl. Acad. Sci. U.S.A. 95:10328-10333.

Eulgem, T., and Somssich, I. E. 2007. Networks of WRKY transcription factors in defense signaling. Curr. Opin. Plant Biol. 10:366-371.

Eulgem, T., Rushton, P. J., Schmelzer, E., Hahlbrock, K., and Somssich, I. E. 1999. Early nuclear events in plant defence signalling: Rapid gene activation by WRKY transcription factors. EMBO (Eur. Mol. Biol. Organ.) J. 18:4689-4699.

Eulgem, T., Rushton, P. J., Robatzek, S., and Somssich, I. E. 2000. The 
WRKY superfamily of plant transcription factors. Trends Plant Sci. 5:199-206.

Eulgem, T., Weigman, V. J., Chang, H. S., McDowell, J. M., Holub, E. B., Glazebrook, J., Zhu, T., and Dangl, J. L. 2004. Gene expression signatures from three genetically separable resistance gene signaling pathways for downy mildew resistance. Plant Physiol. 135:1129-1144.

Eulgem, T., Tsuchiya, T., Wang, X. J., Beasley, B., Cuzick, A., Tor, M., Zhu, T., McDowell, J. M., Holub, E., and Dangl, J. L. 2007. EDM2 is required for RPP7-dependent disease resistance in Arabidopsis and affects RPP7 transcript levels. Plant J. 49:829-839.

Falk, A., Feys, B. J., Frost, L. N., Jones, J. D., Daniels, M. J., and Parker, J. E. 1999. EDS1, an essential component of $R$ gene-mediated disease resistance in Arabidopsis has homology to eukaryotic lipases. Proc. Natl. Acad. Sci. U.S.A. 96:3292-3297.

Feys, B. J., and Parker, J. E. 2000. Interplay of signaling pathways in plant disease resistance. Trends Genet. 16:449-455.

Feys, B. J., Moisan, L. J., Newman, M. A., and Parker, J. E. 2001. Direct interaction between the Arabidopsis disease resistance signaling proteins, EDS1 and PAD4. EMBO (Eur. Mol. Biol. Organ.) J. 20:54005411 .

Feys, B. J., Wiermer, M., Bhat, R. A., Moisan, L. J., Medina-Escobar, N., Neu, C., Cabral, A., and Parker, J. E. 2005. Arabidopsis SENESCENCE-ASSOCIATED GENE101 stabilizes and signals within an ENHANCED DISEASE SUSCEPTIBILITY1 complex in plant innate immunity. Plant Cell 17:2601-2613.

Gu, K., Yang, B., Tian, D., Wu, L., Wang, D., Sreekala, C., Yang, F., Chu, Z., Wang, G. L., White, F. F., and Yin, Z. 2005. R gene expression induced by a type-III effector triggers disease resistance in rice. Nature 435:1122-1125

Gutterson, N., and Reuber, T. L. 2004. Regulation of disease resistance pathways by AP2/ERF transcription factors. Curr. Opin. Plant Biol. 7:465-471.

Halterman, D. A., Wei, F., and Wise, R. P. 2003. Powdery mildew-induced Mla mRNAs are alternatively spliced and contain multiple upstream open reading frames. Plant Physiol. 131:558-567.

Higo, K., Ugawa, Y., Iwamoto, M., and Korenaga, T. 1999. Plant cis-acting regulatory DNA elements (PLACE) database: 1999. Nucleic Acids Res. 27:297-300

Holt, B. F., Belkhadir, Y., and Dangl, J. L. 2005. Antagonistic contol of disease resistance protein stability in the plant immune system. Science 309:929-932.

Huang, S., van der Vossen, E. A., Kuang, H., Vleeshouwers, V. G., Zhang, N., Borm, T. J., van Eck, H. J., Baker, B., Jacobsen, E., and Visser, R. G. 2005. Comparative genomics enabled the isolation of the R3a late blight resistance gene in potato. Plant J. 42:251-261.

Jirage, D., Tootle, T. L., Reuber, T. L., Frost, L. N., Feys, B. J., Parker, J. E., Ausubel, F. M., and Glazebrook, J. 1999. Arabidopsis thaliana PAD4 encodes a lipase-like gene that is important for salicylic acid signaling. Proc. Natl. Acad. Sci. U.S.A. 96:13583-13588.

Jones, J. D., and Dangl, J. L. 2006. The plant immune system. Nature 444:323-329

Journot-Catalino, N., Somssich, I. E., Roby, D., and Kroj, T. 2006. The transcription factors WRKY11 and WRKY17 act as negative regulators of basal resistance in Arabidopsis thaliana. Plant Cell 18:3289-3302.

Katagiri, F. 2004. A global view of defense gene expression regulation-a highly interconnected signaling network. Curr. Opin. Plant Biol. 7:506511.

Kim, C. Y., and Zhang, S. 2004. Activation of a mitogen-activated protein kinase cascade induces WRKY family of transcription factors and defense genes in tobacco. Plant J. 38:142-151.

Kim, K.-C., Lai, Z., Fan, B., and Chen, Z. 2008. Arabidopsis WRKY38 and WRKY62 transcription factors interact with histone deacetylase 19 in basal defense. Plant Cell 20:2357-2371.

Knoth, C., Ringler, J., Dangl, J. L., and Eulgem, T. 2007. Arabidopsis WRKY70 is required for full RPP4-mediated disease resistance and basal defense against Hyaloperonospora parasitica. Mol. Plant-Microbe Interact. 20:120-128.

Kramer, L. C., Choudoir, M. J., Wielgus, S. M., Bhaskar, P. B., and Jiang, J. 2009. Correlation between transcript abundance of the RB gene and the level of the RB-mediated late blight resistance in potato. Mol. PlantMicrobe Interact. 22:447-455.

Laloi, C., Mestres-Ortega, D., Marco, Y., Meyer, Y., and Reichheld, J. P. 2004. The Arabidopsis cytosolic thioredoxin $h 5$ gene induction by oxidative stress and its W-box-mediated response to pathogen elicitor. Plant Physiol. 134:1006-1016.

Lebel, E., Heifetz, P., Thorne, L., Uknes, S., Ryals, J., and Ward, E. 1998. Functional analysis of regulatory sequences controlling PR-1 gene expression in Arabidopsis. Plant J. 16:223-233.

Lescot, M., Dehais, P., Thijs, G., Marchal, K., Moreau, Y., Van de Peer, Y., Rouze, P., and Rombauts, S. 2002. PlantCARE, a database of plant cis- acting regulatory elements and a portal to tools for in silico analysis of promoter sequences. Nucleic Acids Res. 30:325-327.

Levy, M., Edelbaum, O., and Sela, I. 2004. Tobacco mosaic virus regulates the expression of its own resistance gene N. Plant Physiol. 135:23922397

Li, Y., Yang, S., Yang, H., and Hua, J. 2007. The TIR-NB-LRR gene SNC1 is regulated at the transcript level by multiple factors. Mol. Plant-Microbe Interact. 20:1449-1456.

Li, Y., Pennington, B. O., and Hua, J. 2009. Multiple $R$-like genes are negatively regulated by BON1 and BON3 in Arabidopsis. Mol. PlantMicrobe Interact. 22:840-848.

Maleck, K., Levine, A., Eulgem, T., Morgan, A., Schmid, J., Lawton, K. A., Dangl, J. L., and Dietrich, R. A. 2000. The transcriptome of Arabidopsis thaliana during systemic acquired resistance. Nat. Genet. 26:403-410.

McDowell, J. M., and Dangl, J. L. 2000. Signal transduction in the plant immune response. Trends Biochem. Sci. 25:79-82.

McDowell, J. M., Dhandaydham, M., Long, T. A., Aarts, M. G., Goff, S., Holub, E. B., and Dangl, J. L. 1998. Intragenic recombination and diversifying selection contribute to the evolution of downy mildew resistance at the RPP8 locus of Arabidopsis. Plant Cell 10:1861-1874.

McDowell, J. M., Cuzick, A., Can, C., Beynon, J., Dangl, J. L., and Holub, E. B. 2000. Downy mildew (Peronospora parasitica) resistance genes in Arabidopsis vary in functional requirements for NDR1, EDS1, NPR1 and salicylic acid accumulation. Plant J. 22:523-529.

McDowell, J. M., Williams, S. G., Funderburg, N. T., Eulgem, T., and Dangl, J. L. 2005. Genetic analysis of developmentally regulated resistance to downy mildew (Hyaloperonospora parasitica) in Arabidopsis thaliana. Mol. Plant-Microbe Interact. 18:1226-1234.

Mes, J. J., van Doorn, A. A., Wijbrandi, J., Simons, G., Cornelissen, B. J., and Haring, M. A. 2000. Expression of the Fusarium resistance gene I2 colocalizes with the site of fungal containment. Plant J. 23:183-193.

Meyers, B. C., Kozik, A., Griego, A., Kuang, H. H., and Michelmore, R. W. 2003. Genome-wide analysis of NBS-LRR-encoding genes in Arabidopsis. Plant Cell 15:809-834.

Meyers, B. C., Lee, D. K., Vu, T. H., Tej, S. S., Edberg, S. B., Matvienko, M., and Tindell, L. D. 2004. Arabidopsis MPSS. An online resource for quantitative expression analysis. Plant Physiol. 135:801-813.

Navarro, L., Zipfel, C., Rowland, O., Keller, I., Robatzek, S., Boller, T., and Jones, J. D. 2004. The transcriptional innate immune response to flg22. Interplay and overlap with Avr gene-dependent defense responses and bacterial pathogenesis. Plant Physiol. 135:1113-1128.

Nishimura, N., Yoshida, T., Kitahata, N., Asami, T., Shinozaki, K., and Hirayama, T. 2007. ABA-Hypersensitive Germination1 encodes a protein phosphatase $2 \mathrm{C}$, an essential component of abscisic acid signaling in Arabidopsis seed. Plant J. 50:935-949.

O'Connor, T. R., Dyreson, C., and Wyrick, J. J. 2005. Athena: A resource for rapid visualization and systematic analysis of Arabidopsis promoter sequences. Bioinformatics 21:4411-4413.

Ohler, U., and Niemann, H. 2001. Identification and analysis of eukaryotic promoters: Recent computational approaches. Trends Genet. 17:56-60.

Pandey, S. P., and Somssich, I. E. 2009. The role of WRKY tTranscription factors in plant immunity. Plant Physiol. 150:1648-1655.

Qiu, J.-L., Zhou, L., Yun, B.-W., Nielsen, H. B., Fiil, B. K., Petersen, K. MacKinlay, J., Loake, G. J., Mundy, J., and Morris, P. C. 2008. Arabidopsis mitogen-activated protein kinase kinases MKK1 and MKK2 have overlapping functions in defense signaling mediated by MEKK1, MPK4, and MKS1. Plant Physiol. 148:212-222.

Reignault, P., Frost, L. N., Richardson, H., Daniels, M. J., Jones, J. D., and Parker, J. E. 1996. Four Arabidopsis RPP loci controlling resistance to the Noco2 isolate of Peronospora parasitica map to regions known to contain other RPP recognition specificities. Mol. Plant-Microbe Interact. 9:464-473.

Romer, P., Hahn, S., Jordan, T., Strauss, T., Bonas, U., and Lahaye, T. 2007. Plant pathogen recognition mediated by promoter activation of the pepper Bs3 resistance gene. Science 318:645-648.

Rushton, P. J., Reinstadler, A., Lipka, V., Lippok, B., and Somssich, I. E. 2002. Synthetic plant promoters containing defined regulatory elements provide novel insights into pathogen- and wound-induced signaling. Plant Cell 14:749-762.

Schulze-Lefert, P. 2004. Plant immunity: The origami of receptor activation. Curr. Biol. 14:R22-24.

Shah, J. 2003. The salicylic acid loop in plant defense. Curr. Opin. Plant Biol. 6:365-371.

Shen, Q. H., Saijo, Y., Mauch, S., Biskup, C., Bieri, S., Keller, B., Seki, H., Ulker, B., Somssich, I. E., and Schulze-Lefert, P. 2007. Nuclear activity of MLA immune receptors links isolate-specific and basal disease-resistance responses. Science 315:1098-1103.

Shirano, Y., Kachroo, P., Shah, J., and Klessig, D. F. 2002. A gain-of-function mutation in an Arabidopsis Toll Interleukin1 receptor-nucleotide 
binding site-leucine-rich repeat type $R$ gene triggers defense responses and results in enhanced disease resistance. Plant Cell 14:3149-3162.

Shirasu, K., and Schulze-Lefert, P. 2003. Complex formation, promiscuity and multi-functionality: Protein interactions in disease-resistance pathways. Trends Plant Sci. 8:252-258.

Shirasu, K., Nakajima, H., Rajasekhar, V. K., Dixon, R. A., and Lamb, C. J. 1997. Salicylic acid potentiates an agonist-dependent gain control that amplifies pathogen signals in the activation of defense mechanisms. Plant Cell 9:261-270.

Singh, K., Foley, R. C., and Onate-Sanchez, L. 2002. Transcription factors in plant defense and stress responses. Curr. Opin. Plant Biol. 5:430-436.

Stelling, J., Sauer, U., Szallasi, Z., Doyle, F. J., 3rd, and Doyle, J. 2004. Robustness of cellular functions. Cell 118:675-685.

Stokes, T. L., Kunkel, B. N., and Richards, E. J. 2002. Epigenetic variation in Arabidopsis disease resistance. Genes Dev. 16:171-182.

Takahashi, H., Miller, J., Nozaki, Y., Takeda, M., Shah, J., Hase, S., Ikegami, M., Ehara, Y., and Dinesh-Kumar, S. P. 2002. RCY1, an Arabidopsis thaliana RPP8/HRT family resistance gene, conferring resistance to Cucumber mosaic virus requires salicylic acid, ethylene and a novel signal transduction mechanism. Plant J. 32:655-667.

Takken, F. L., and Tameling, W. I. 2009. To nibble at plant resistance proteins. Science 324:744-746.

Tan, X., Meyers, B. C., Kozik, A., West, M. A., Morgante, M., St. Clair, D. A., Bent, A. F., and Michelmore, R. W. 2007. Global expression analysis of nucleotide binding site-leucine rich repeat-encoding and related genes in Arabidopsis. BMC Plant Biol. 7:56.

Tao, Y., Yuan, F., Leister, R. T., Ausubel, F. M., and Katagiri, F. 2000. Mutational analysis of the Arabidopsis nucleotide binding site-leucinerich repeat resistance gene RPS2. Plant Cell 12:2541-2554.

Thomma, B., Eggermont, K., Penninckx, I., Mauch-Mani, B., Vogelsang, R., Cammue, B. P. A., and Broekaert, W. F. 1998. Separate jasmonatedependent and salicylate-dependent defense-response pathways in Arabidopsis are essential for resistance to distinct microbial pathogens. Proc. Natl. Acad. Sci. U.S.A. 95:15107-15111.

Tian, D., Traw, M. B., Chen, J. Q., Kreitman, M., and Bergelson, J. 2003. Fitness costs of $R$-gene-mediated resistance in Arabidopsis thaliana. Nature 423:74-77.

Toufighi, K., Brady, S. M., Austin, R., Ly, E., and Provart, N. J. 2005. The Botany Array Resource: e-Northerns, expression angling, and promoter analyses. Plant J. 43:153-163.

Turck, F., Zhou, A., and Somssich, I. E. 2004. Stimulus-dependent, promoter-specific binding of transcription factor WRKY1 to its native promoter and the defense-related gene PcPRl-1 in parsley. Plant Cell 16:2573-2585.

van der Biezen, E. A., Freddie, C. T., Kahn, K., Parker, J. E., and Jones, J. D. 2002. Arabidopsis RPP4 is a member of the RPP5 multigene family of TIR-NB-LRR genes and confers downy mildew resistance through multiple signalling components. Plant J. 29:439-451.

Venugopal, S. C., Jeong, R. D., Mandal, M. K., Zhu, S., Chandra-Shekara, A. C., Xia, Y., Hersh, M., Stromberg, A. J., Navarre, D., Kachroo, A., and Kachroo, P. 2009. Enhanced disease susceptibility 1 and salicylic acid act redundantly to regulate resistance gene-mediated signaling. PLoS Genet. 5:e1000545. Published online.

Wang, D., Weaver, N. D., Kesarwani, M., and Dong, X. 2005. Induction of protein secretory pathway is required for systemic acquired resistance. Science 308:1036-1040.

Wang, D., Amornsiripanitch, N., and Dong, X. 2006. A genomic approach to identify regulatory nodes in the transcriptional network of systemic acquired resistance in plants. PLoS Pathog. 2:e123. Published online.

Wang, Z. X., Yamanouchi, U., Katayose, Y., Sasaki, T., and Yano, M. 2001. Expression of the Pib rice-blast-resistance gene family is up-regulated by environmental conditions favouring infection and by chemical signals that trigger secondary plant defences. Plant Mol. Biol. 47:653-661.

Wiermer, M., Feys, B. J., and Parker, J. E. 2005. Plant immunity: The EDS1 regulatory node. Curr. Opin. Plant Biol. 8:383-389.

Wildermuth, M. C., Dewdney, J., Wu, G., and Ausubel, F. M. 2001. Isochorismate synthase is required to synthesize salicylic acid for plant defence. Nature 414:562-565.

Xiao, S. Y., Brown, S., Patrick, E., Brearley, C., and Turner, J. G. 2003. Enhanced transcription of the Arabidopsis disease resistance genes RPW8.1 and RPW8.2 via a salicylic acid-dependent amplification circuit is required for hypersensitive cell death. Plant Cell 15:33-45.

Yang, S., and Hua, J. 2004. A haplotype-specific Resistance gene regulated by BONZAI1 mediates temperature-dependent growth control in Arabidopsis. Plant Cell 16:1060-1071.

Yi, H., and Richards, E. J. 2007. A cluster of disease resistance genes in Arabidopsis is coordinately regulated by transcriptional activation and RNA silencing. Plant Cell 19:2929-2939.

Yoshimura, S., Yamanouchi, U., Katayose, Y., Toki, S., Wang, Z. X., Kono, I., Kurata, N., Yano, M., Iwata, N., and Sasaki, T. 1998. Expression of $\mathrm{Xa1}$, a bacterial blight resistance gene, is induced by bacterial inoculation. . Proc. Natl. Acad. Sci. U.S.A. 95:1663-1668.

Yu, D., Chen, C., and Chen, Z. 2001. Evidence for an important role of WRKY DNA binding proteins in the regulation of NPR1 gene expression. Plant Cell 13:1527-1540.

Zimmermann, P., Hirsch-Hoffmann, M., Hennig, L., and Gruissem, W. 2004. GENEVESTIGATOR. Arabidopsis microarray database and analysis toolbox. Plant Physiol. 136:2621-2632.

Zimmermann, P., Hennig, L., and Gruissem, W. 2005. Gene-expression analysis and network discovery using Genevestigator. Trends Plant Sci. 10:407-409.

Zipfel, C., Robatzek, S., Navarro, L., Oakeley, E. J., Jones, J. D., Felix, G., and Boller, T. 2004. Bacterial disease resistance in Arabidopsis through flagellin perception. Nature 428:764-767.

\section{AUTHOR-RECOMMENDED INTERNET RESOURCE}

University of California Davis Functional and Comparative Genomics of Disease Resistance Gene Homologs database: niblrrs.ucdavis.edu 